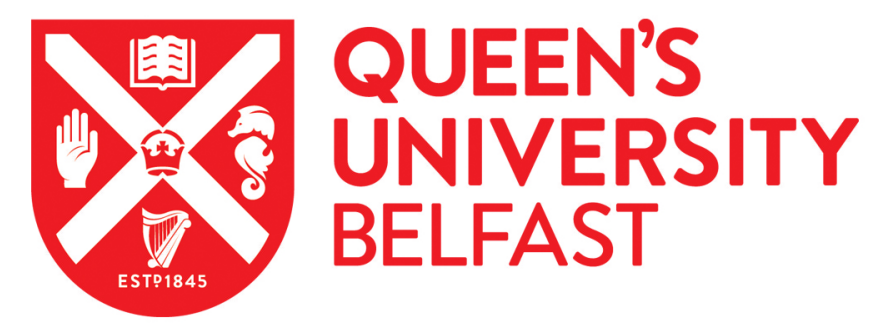

\title{
Preliminary investigation of mixed adsorbents for the removal of copper and methylene blue from aqueous solutions
}

\author{
Albadarin, A., Mo, J., Glocheux, Y., Allen, S., Walker, G., \& Mangwandi, C. (2014). Preliminary investigation of \\ mixed adsorbents for the removal of copper and methylene blue from aqueous solutions. Chemical Engineering \\ Journal, 255, 525. https://doi.org/10.1016/j.cej.2014.06.029
}

Published in:

Chemical Engineering Journal

Document Version:

Early version, also known as pre-print

Queen's University Belfast - Research Portal:

Link to publication record in Queen's University Belfast Research Portal

\footnotetext{
General rights

Copyright for the publications made accessible via the Queen's University Belfast Research Portal is retained by the author(s) and / or other copyright owners and it is a condition of accessing these publications that users recognise and abide by the legal requirements associated with these rights.

Take down policy

The Research Portal is Queen's institutional repository that provides access to Queen's research output. Every effort has been made to ensure that content in the Research Portal does not infringe any person's rights, or applicable UK laws. If you discover content in the Research Portal that you believe breaches copyright or violates any law, please contact openaccess@qub.ac.uk.
} 


\section{Elsevier Editorial System(tm) for Chemical Engineering Journal}

Manuscript Draft

Manuscript Number: CEJ-D-14-01907R1

Title: Preliminary investigation of mixed adsorbents for the removal of copper and methylene blue from aqueous solutions

Article Type: Research Paper

Keywords: Multi-adsorbents; Wastewater; Adsorption technique; Heavy metals; Dyes

Corresponding Author: Dr. Ahmad B. Albadarin, Ph.D

Corresponding Author's Institution: University of Limerick

First Author: Ahmad B. Albadarin, Ph.D

Order of Authors: Ahmad B. Albadarin, Ph.D; Jiabin Mo, MSc; Yoann Glocheux, PhD; Gavin walker, PhD; Stephen Allen, PhD; Chirangano Mangwandi, PhD

Abstract: With most recent studies being focused on the development of advanced chemical adsorbents, this paper investigates the possibility of using two natural low-cost materials for selective adsorption. Multi-adsorbent systems containing tea waste (TW) and dolomite (DO) have been tested for their effectiveness in the removal of copper and methylene blue from aqueous solutions. The effects of contact time, solution $\mathrm{pH}$ and adsorption isotherms on the sorption behaviour were investigated. The Langmuir and Freundlich isotherms adequately described the adsorption of copper ions and methylene blue by both materials in different systems. The highest adsorption capacities for $\mathrm{Cu}$ and MB were calculated as $237.7 \mathrm{mg} / \mathrm{g}$ at $\mathrm{pH} 4.5$ and $150.4 \mathrm{mg} / \mathrm{g}$ at pH 7 for DO and TW:DO respectively. Tea waste and dolomite were characterized by Fourier transform infrared spectroscopy, scanning electron microscopy and Energy dispersive X-ray analysis. The removal of $\mathrm{Cu}$ and $\mathrm{MB}$ by dolomite was mainly via surface complexation while physisorption was responsible for most of the $\mathrm{Cu}$ and $\mathrm{MB}$ adsorption onto tea waste. Identifying the fundamental mechanisms and behaviour is key to the development of practical multi-adsorbent packed columns.

Response to Reviewers: RESPONSE TO REVIEWERS:

Authors would like to thank the reviewers for very constructive comments. We believe that addressing the reviewer's concerns has led to improvements in the manuscript.

The following explains how we handled the comments raised by reviewers.

Response to Reviewer No 1:

It is a very good study which aims the investigation of adsorption/removal of a heavy metal (copper) and a dye (methylene blue) using low-cost adsorbent. My comments are listed below.

1. Fig.1 presents the kinetic data without fitting, while Fig.2 after fitting. I recommend authors to move Fig.1 to Supporting information section.

Answer: Figure 1 has been moved to the Supplementary data as recommended.

2. Fig. 4 has 6 sub-figs without numbering. But, I think they need merging into at least 2 sub-figs and not 6 . 
Answer: Putting these figures in 2 sub-figures will not allow clear demonstration of the data and isotherm fitting. However, Figure 4 was spilt into 2 figures.

3. The major absorbencies (as described in text) should be illustrated in Fig.6, 7 (FTIR). Answer: There are so many peaks and adding them to the figures will make it hard to notice the changes in the sample surface before and after adsorption.

4. It will be good to add a column in Table 1 (for each fitting), presenting the \%change between Qe,exp and Qe,cal.

Answer: The qe,exp and qe,cal values have been discussed in the manuscript and there is no need to represent the change between them in the table.

5. Authors should illustrate (as scheme/figure) an adsorption mechanism based on their findings (FTIR, etc). It is more attractive for any reader to read and follow a figure than only text.

Answer: A new figure (Figure 6) has been added. The figure illustrates the possible removal mechanisms for copper and methylene blue onto dolomite and tea waste.

Response to Reviewer No 2:

6. In table 3 the Redlich-Peterson model capacity is not comparable with the Langmuir model capacities. This capacity must be omitted.

Answer: The Redlich-Peterson model has not been employed to describe the isotherm experimental data in this study.

7. Figure 1 gives no essential information and can be omitted.

Answer: As per Reviewer 1 suggestion, Figure 1 has been moved to the supplementary data section.

Response to Reviewer No 3:

8. $\quad$ There are several technical errors:

Page 6: row 129 "The $\mathrm{Cr}(\mathrm{VI})$ percentage removal...". It should be $\mathrm{Cu}(\mathrm{II})$.

There are two tables numbered as No 3. Table 3.Comparison of adsorption capacities...has to be mentioned in the text.

Answer: The manuscript was revised and all typo mistakes have been corrected. 


\section{Dear Editor,}

On behalf of myself and my colleagues (co-authors of this work), please find attached an electronic copy of the manuscript "Preliminary investigation of mixed adsorbents for the removal of copper and methylene blue from aqueous solutions" submitted to "Chemical Engineering Journal" for possible publication.

This work is original and has not been submitted nor published anywhere else. The findings and results in this work are novel and have not been taken from any other source.

I will be really thankful if you consider this work for possible publication in this reputable Journal.

Best Regards,

Dr Ahmad Albadarin, PhD.

Materials Surface Science Institute,

Department of Chemical and Environmental Sciences,

University of Limerick, Ireland 


\section{RESPONSE TO REVIEWERS:}

Authors would like to thank the reviewers for very constructive comments. We believe that addressing the reviewer's concerns has led to improvements in the manuscript.

The following explains how we handled the comments raised by reviewers.

\section{Response to Reviewer No 1:}

It is a very good study which aims the investigation of adsorption/removal of a heavy metal (copper) and a dye (methylene blue) using low-cost adsorbent. My comments are listed below.

1. Fig.1 presents the kinetic data without fitting, while Fig. 2 after fitting. I recommend authors to move Fig.1 to Supporting information section.

Answer: Figure 1 has been moved to the Supplementary data as recommended.

2. Fig. 4 has 6 sub-figs without numbering. But, I think they need merging into at least 2 subfigs and not 6.

Answer: Putting these figures in 2 sub-figures will not allow clear demonstration of the data and isotherm fitting. However, Figure 4 was spilt into 2 figures.

3. The major absorbencies (as described in text) should be illustrated in Fig.6, 7 (FTIR).

Answer: There are so many peaks and adding them to the figures will make it hard to notice the changes in the sample surface before and after adsorption.

4. It will be good to add a column in Table 1 (for each fitting), presenting the \%change between Qe,exp and Qe,cal.

Answer: The qe,exp and qe,cal values have been discussed in the manuscript and there is no need to represent the change between them in the table.

5. Authors should illustrate (as scheme/figure) an adsorption mechanism based on their findings (FTIR, etc). It is more attractive for any reader to read and follow a figure than only text.

Answer: A new figure (Figure 6) has been added. The figure illustrates the possible removal 
mechanisms for copper and methylene blue onto dolomite and tea waste.

Response to Reviewer No 2:

6. In table 3 the Redlich-Peterson model capacity is not comparable with the Langmuir model capacities. This capacity must be omitted.

Answer: The Redlich-Peterson model has not been employed to describe the isotherm experimental data in this study.

7. Figure 1 gives no essential information and can be omitted.

Answer: As per Reviewer 1 suggestion, Figure 1 has been moved to the supplementary data section.

Response to Reviewer No 3:

8. There are several technical errors:

Page 6: row 129 "The $\mathrm{Cr}(\mathrm{VI})$ percentage removal...". It should be $\mathrm{Cu}(\mathrm{II})$. There are two tables numbered as No 3. Table 3.Comparison of adsorption capacities...has to be mentioned in the text.

Answer: The manuscript was revised and all typo mistakes have been corrected. 


\section{RESEARCH HIGHLIGHTS:}

- Multi-adsorbent systems containing tea waste (TW) and dolomite (DO) have been tested.

- The effects of contact time, solution $\mathrm{pH}$ and adsorption isotherms were investigated.

- Adsorption capacities for $\mathrm{Cu}$ and MB were calculated as 237.7 and $150.4 \mathrm{mg} . \mathrm{g}^{\square 1}$ for DO and TW:DO respectively.

- Solution pH had little effect on the capacity of the TW:DO system, specifying that the system has good potential for practical use. 
1 Preliminary investigation of mixed adsorbents for the removal of copper and methylene 2 blue from aqueous solutions

3

4 Ahmad B. Albadarin ${ }^{1,2}$, Jiabin Mo ${ }^{1}$, Yoann Glocheux ${ }^{1}$, Stephen Allen ${ }^{1}$, Gavin Walker ${ }^{1,2}$, Chirangano Mangwandi ${ }^{1} *$

7

8

$9{ }^{1}$ Materials Surface Science Institute, Department of Chemical and Environmental Sciences,

10 University of Limerick, Ireland

$11{ }^{2}$ School of Chemistry and Chemical Engineering, Queen's University Belfast, Belfast BT9

$125 A G$, Northern Ireland, $U K$.

*Corresponding Author 


\section{Abstract}

27 With most recent studies being focused on the development of advanced chemical 28 adsorbents, this paper investigates the possibility of using two natural low-cost materials for selective adsorption. Multi-adsorbent systems containing tea waste (TW) and dolomite (DO)

30 have been tested for their effectiveness in the removal of copper and methylene blue from aqueous solutions. The effects of contact time, solution $\mathrm{pH}$ and adsorption isotherms on the sorption behaviour were investigated. The Langmuir and Freundlich isotherms adequately described the adsorption of copper ions and methylene blue by both materials in different systems. The highest adsorption capacities for $\mathrm{Cu}$ and $\mathrm{MB}$ were calculated as $237.7 \mathrm{mg} / \mathrm{g}$ at $\mathrm{pH} 4.5$ and $150.4 \mathrm{mg} / \mathrm{g}$ at $\mathrm{pH} 7$ for DO and TW:DO respectively. Tea waste and dolomite were characterized by Fourier transform infrared spectroscopy, scanning electron microscopy and Energy dispersive X-ray analysis. The removal of $\mathrm{Cu}$ and $\mathrm{MB}$ by dolomite was mainly via surface complexation while physisorption was responsible for most of the $\mathrm{Cu}$ and $\mathrm{MB}$ adsorption onto tea waste. Identifying the fundamental mechanisms and behaviour is key to the development of practical multi-adsorbent packed columns. 


\section{Introduction}

52

53

Dyes (very frequently methylene blue and methyl orange) and heavy metals (copper, cadmium and nickel mostly from the organo-metallic dyes) are dangerous pollutants found in large quantities in wastewaters from textile and paper industries. It is known that heavy metals are toxic and non-biodegradable [1, 2]. Heavy metals have many environmental issues such as animal and plant death, reduced rates of reproduction and the decrease of ecosystem diversity [3]. While dyes are difficult to treat as the colour tends to hold strong even after the conventional removal processes [4]. There are more than 100,000 commercially available dyes with over 700,000 tons produced annually [5]. The presence of some of these dyes even in very small amounts i.e. $<1 \mathrm{mg} \cdot \mathrm{dm}^{-3}$ is undesirable $[6,7]$. DyesHeavy metal loaded wastewaters are highly coloured, have a fluctuating $\mathrm{pH}$ and regularly contain large amounts of suspended oils. Dyes and heavy metals find their way into the environment, primarily dissolved or suspended in water everyday [8] and create serious damage to the environment by changing the biological life balance in rivers and lakes $[9,10]$. Adsorption is a well-established and powerful practice for the removal of dyes and heavy metal pollutants from wastewaters. For these reasons, thousands of investigations have used uncountable adsorbents to remove heavy metals [11] or dyes [12]. Most of these studies focus on single-component aqueous solutions and recently, more research papers have been published dealing with the adsorption of dyes and metals in multi-component aqueous systems [6]. Also, composite adsorbents have been established to adsorb dyes and heavy metals from wastewater such as chitosan/montmorillonite composites [13-15] and fly ash/activated carbon [16]. In previous studies, composite materials were used to selectively adsorb a particular pollutant. Ho and co-workers proved that amino functionalized silica solids can selectively adsorb dye anthraquinone blue in the presence of methylene blue, while, from the same dye mixture, carboxy-functionalized materials adsorb methylene blue 
selectively [17]. Prediction of multicomponent adsorption is still one of the most challenging problems in the adsorption field [18]. There is little data available to provide more understanding about the interactions between adsorbents and developing design models for such practical systems is very important [19]. This is the case for many composite materials as well as adsorption processes with multi-adsorbate and multi-adsorbent systems. Dolomite, with a structure of alternative layers of calcite and magnesite, is a potential inexpensive and readily available adsorbent [20]. Many studies showed that dolomite and charred dolomite have the potential to act as adsorbents for reactive dyes and heavy metals [21]. Tea, processed leaves from Camellia sinensis species, is the second most common drink being consumed after water with an average daily drinking of 20 billion cups. The producers of making tea drinks face a problem in disposing of the spent tea leaves after the extraction [22, 23]. The feasibility of using the richly available solid waste, spent tea leaves, for the removal of heavy metals and dyes has also been extensively investigated [24]. A good understanding of the effect of adsorbent-adsorbent interactions on selective adsorption is essential as a foundation for selecting the best adsorbent and employing it in an optimal way. Hence, the aim of this research is to clarify the chemical and physical interferences between the two materials, namely tea waste and dolomite, when used for the removal of copper and methylene blue from aqueous solutions. In this paper, the term adsorption will refer to biosorption onto tea waste (TW) and adsorption onto dolomite (DO). Copper ions and methylene blue dye adsorption onto tea waste and dolomite using different factors, such as reaction contact time and $\mathrm{pH}$ of solution as well as initial metal and dye concentration on selective adsorption was examined. Recognizing the fundamental mechanisms and behaviour would be useful for practical multi-adsorbent packed columns. 


\section{Materials and Methods}

\subsection{Adsorbents and adsorbents}

103 The two low cost materials used in this experiment were tea waste (TW) biosorbent and 104 dolomite (DO) adsorbent. Fine Dolomite $\left(\mathrm{d}_{\mathrm{P}}<50 \mu \mathrm{m}\right)$ was supplied by Killwaughter

105 Chemical Company, UK. The typical chemical composition of the dolomite in the deposit 106 was $44 \% \mathrm{MgCO}_{3}$ and $53 \% \mathrm{CaCO}_{3}$ (obtained by XRD analysis) [25]. The tea waste

107 biosorbent was collected from Queen's University cafeteria; it was washed several times with 108 hot water and dried in a conventional oven at $110{ }^{\circ} \mathrm{C}$. The two adsorbents were 109 comprehensively characterized in previous investigations [26, 27]. Copper(II) and Methylene

110 Blue (MB) stock solutions were prepared by dissolving known amounts of $\mathrm{CuSO}_{4} \cdot 5 \mathrm{H}_{2} \mathrm{O}$ and $111 \mathrm{MB}$ in deionised water. The stock solutions were then diluted to get various initial 112 concentrations. All chemicals were purchased from Sigma Aldrich UK.

\section{2.2. Adsorption Experiment}

114 To investigate the influence of $\mathrm{pH}$ on $\mathrm{Cu}(\mathrm{II})$ and $\mathrm{MB}$ adsorption onto $\mathrm{TW}$ and $\mathrm{DO}$, six sets of 115 experiments were prepared: $\mathrm{Cu}(\mathrm{II})$ or $\mathrm{MB}$ with $\mathrm{TW}$ biosorbent; $\mathrm{Cu}(\mathrm{II})$ or $\mathrm{MB}$ with $\mathrm{DO}$ 116 adsorbent and $\mathrm{Cu}(\mathrm{II})$ or MB with a mixture of 1:1 TW:DO (w/w\%). Samples of $25 \mathrm{~cm}^{3}$ of

117 adsorbate solutions with $C_{\mathrm{o}}=120$ and $100 \mathrm{mg} / \mathrm{dm}^{3}$ of $\mathrm{Cu}$ and $\mathrm{MB}$, respectively, were 118 adjusted to different $\mathrm{pH}$ values: $2-11$. The same procedures were performed to study the 119 effect of contact time and adsorption isotherms. The initial concentrations of $\mathrm{Cu}$ (II) for the 120 contact time studies was $200 \mathrm{mg} / \mathrm{dm}^{3}$ and for MB it was $120 \mathrm{mg} / \mathrm{dm}^{3}$. For the adsorption 121 isotherm studies, a concentration of: $C_{\mathrm{o}}=10-100 \mathrm{mg} / \mathrm{dm}^{3}$ for $\mathrm{Cu}(\mathrm{II})$ and $C_{\mathrm{o}}=10-75 \mathrm{mg} / \mathrm{dm}^{3}$

122 for MB were used. An adsorbent dose of $1 \mathrm{~g} / \mathrm{dm}^{3}$ was used for all experiments at room 123 temperature $\left(\sim 20^{\circ} \mathrm{C}\right)$ and a contact time of 4 days to ensure reaching the equilibrium. There 124 were no $\mathrm{pH}$ adjustments for contact time and isotherm experiments, so the experimental 125 processes are more environmental friendly. The concentrations of $\mathrm{Cu}(\mathrm{II})$ and $\mathrm{MB}$ were 
126 analysed using an ICP- OES Thermo Scientific IRIS and UV/Vis spectrophotometer (Perkin

127 Elmer LAMBDA 25, UK), respectively. The amount of $\mathrm{Cu}(\mathrm{II})$ and $\mathrm{MB}$ adsorbed per unit

128 mass of adsorbent $q$ in $(\mathrm{mg} / \mathrm{g})$ and removal percentage were calculated using Eq. (1) and Eq.

129 (2):

130 The percentage removal $=\left[1-\frac{C_{e}}{C_{o}}\right] \times 100 \%$

$131 q=\left[\frac{C_{o}-C_{e}}{M}\right] \times V$

132 Where $C_{\mathrm{o}}$ and $C_{\mathrm{e}}(\mathrm{mg} / \mathrm{L})$ are the concentration of adsorbate at initial and equilibrium, respectively, $M$ is the mass of adsorbent $(\mathrm{g})$ and $V$ is the volume $\left(\mathrm{dm}^{3}\right)$.

134 2.3. Infrared and SEM measurement

135 The FT-IR analyses for TW and DO surfaces before and after $\mathrm{Cu}(\mathrm{II})$ and MB adsorption were

136 carried out on a Perkin Elmer Spectrum 100 within the range of $400-4000 \mathrm{~cm}^{-1}$. For the

137 SEM analysis and Energy dispersive X-ray (EDX) analysis, TW and DO samples were 138 coated with carbon and vacuumed (5-10 $\mathrm{min})$ for electron reflection prior to analysis on a 139 JEOL-JSM 6400 scanning microscope.

140

141

142

143

144

145

146 


\subsection{Effect of contact time}

149 Figures $\mathrm{S} 1$ (a) and (b) are the plots of $\mathrm{Cu}(\mathrm{II})$ and $\mathrm{MB}$ removal against time for TW and DO

150 materials, respectively. It can been seen that $\mathrm{Cu}(\mathrm{II})$ and $\mathrm{MB}$ were almost completely

151 removed by dolomite and tea waste after $6 \mathrm{hrs}$ at room temperature $\left(20^{\circ} \mathrm{C}\right)$. The adsorption of

$152 \mathrm{Cu}(\mathrm{II})$ and $\mathrm{MB}$ dye was fast in the initial stage due to the large number of available binding

153 sites, resulting in a concentration gradient [28]. The removal rate gradually declined with

154 time until equilibrium was achieved. The maximum removal efficiencies of copper ions and

155 MB onto TW and DO were approx. $90 \%$ at $\mathrm{pH}$ of 5-7. The adsorption capacities of $\mathrm{Cu}(\mathrm{II})$

156 and MB were reduced when the two materials were mixed together; this reduction was more

157 significant in the case of $\mathrm{Cu}(\mathrm{II})$. The adsorption capacity of the mixed adsorbent (TW:DO)

158 was reduced to approx. $45 \%$ and $85 \%$ for $\mathrm{Cu}$ and $\mathrm{MB}$, respectively. This reduction is

159 attributed to the change in the sorbent and solution properties such as $\mathrm{pH}_{\mathrm{PZC}}$ and $\mathrm{pH}_{\text {equilibrium }}$

160 [29]. However, results indicate that these pollutants can still be efficiently removed with high

161 selectivity onto the mixed adsorbents.

\section{3.2. Kinetics Modelling}

163 The adsorption mechanism can be investigated using various adsorption kinetics models.

164 The pseudo first- [30] and pseudo second-order [31] models (Eq. 3 and Eq. 4) have been

165 employed to examine the experimental data for the adsorption of $\mathrm{Cu}(\mathrm{II})$ and $\mathrm{MB}$ by nonlinear

166 regression. The pseudo first-order model equation is given as follow:

$167 \quad q_{t}=q_{e}\left(1-e^{-k_{1} t}\right)$

168 The pseudo second-order equation is given as;

169

$q_{t}=\frac{k_{2} q_{e}^{2}}{\left(1+k_{2} q_{e} t\right)} t$

170 The second-order rate constants were used to calculate the initial sorption rate given by: 
172 where $k_{1}(1 / \mathrm{min})$ and $k_{2}(\mathrm{~g} / \mathrm{mg} \min )$ are the rate constants for first order and second-order 173 models.

174 The plots of $q_{\mathrm{t}}$ versus $t$ and values of the constants of kinetic models obtained from the plots

175 are given in Figure 1 and Table 1. From Table 1, the pseudo first- and pseudo second-order 176 models fit the kinetic data with adequate accuracy $\left(R^{2}>0.897\right)$. However, the experimental 177 data demonstrated more agreement with the pseudo second-order model in terms of closer $178 q_{\mathrm{e}, \text { cal }}$ values to $q_{\mathrm{e}, \exp }$ and higher correlation coefficients than the pseudo first-order model. 179 This indicates that the chemical adsorption was the main control process for the TW and DO 180 materials and the uptake capacity is proportional to the number of active sites [32]. Similar 181 trends were reported for the removal of copper onto chitosan-coated sludge [33] and 182 methylene blue onto magnetic graphene-carbon nanotube composite and polyaniline 183 nanotubes base/silica $[34,35]$. The rate constants $\left(k_{1}\right.$ and $\left.k_{2}\right)$ for both $\mathrm{Cu}(\mathrm{II})$ and $\mathrm{MB}$ sorption 184 onto the TW biosorbent are higher than that for the DO adsorbent. This indicates that it is 185 faster for $\mathrm{Cu}(\mathrm{II})$ and $\mathrm{MB}-\mathrm{TW}$ systems to reach a specific fractional uptake. Initial adsorption 186 rate $(h)$ values for $\mathrm{Cu}(\mathrm{II})$ and $\mathrm{MB}$ sorption followed the same trends $(\mathrm{Cu}(\mathrm{II})(89.07-110.9$ $187 \mathrm{mg} / \mathrm{g} \mathrm{min})$ and $\mathrm{MB}(17.56-56.65 \mathrm{mg} / \mathrm{g} \mathrm{min})$. Also, the Elovich equation was used to 188 evaluate the kinetic sorption data. The linear form of the Elovich equation is given in Eq. 6 189 below: $q_{t}=1 / \beta \ln (\alpha \beta)+1 / \beta \ln (t)$

191 where $\alpha$ is the initial adsorption rate $(\mathrm{mg} / \mathrm{g} \mathrm{min})$, whilst $\beta$ is the extent of surface coverage $192(\mathrm{~g} / \mathrm{mg})$ and activation energy of the process.

193 As can be seen in Table 1, the initial sorption rate $(\alpha)$ is lower in the case of sorption onto the 194 DO system, similar to that of rate constants and initial sorption rate $(h)$ in the pseudo second- 
195 order model. The Elovich equation did not fit the experimental data very well with the 196 regression coefficient, $R^{2}$, within $0.659-0.877$, suggesting that sorption systems of this study

197 are maybe homogeneous.

198

199

201

\subsection{Effect of solution pH}

The $\mathrm{pH}$ parameter is associated with the adsorption mechanisms onto the adsorbent/biomass surfaces from water and determines the magnitude of the electrostatic charges [36]. From Figure 2, it can be observed that the uptake of $\mathrm{Cu}(\mathrm{II})$ onto the $\mathrm{DO}$ is significantly increased from $39 \%$ of removal at $\mathrm{pH} 2$ to a maximum removal of $89 \%$ at $\mathrm{pH} 4.5$. At this $\mathrm{pH}$ value, the main species of copper are $\mathrm{Cu}(\mathrm{II})$ free ions which are primarily involved in the removal process. With a $\mathrm{pH}$ value greater than 6 , immediate precipitation of copper hydroxide takes place especially for high concentration of $\mathrm{Cu}(\mathrm{II})$ ions hindering the adsorption or biosorption processes [37]. The adsorption capacity of $\mathrm{Cu}$ (II) onto TW was notably lower at $\mathrm{pH} 4.5$ with a maximum percentage removal of $39 \%$ at $\mathrm{pH} 5.5$. The relatively lower $\mathrm{Cu}$ (II) removal onto TW can be attributed to the surface chemistry properties of TW such as; the surface point of zero charge. The PZC was previously determined to be $\mathrm{pH}=4$ [27] and had an important effect on the equilibrium ( $\mathrm{pH}_{\text {equilibrium }}$ ). For example, the $\mathrm{Cu}(\mathrm{II})$ solution with a $\mathrm{pH}_{\mathrm{o}}=5.5$ decreased to $\mathrm{pH}_{\mathrm{eq}}=4.2$ after being put in contact with TW for 4 days. Similar trends were observed for the biosorption of $\mathrm{Cd}(\mathrm{II})$ onto sawdust [1]. Also, it was found that the equilibrium $\mathrm{pH}$ for $\mathrm{MB}$ solution at $\mathrm{pH}_{\mathrm{o}}=10$ was reduce to $\mathrm{pH}_{\mathrm{eq}}=8.8$ when using the TW:DO mixed adsorbent. However, MB was efficiently removed by TW over the $\mathrm{pH}$ range studied, which is attributable to the electrostatic attraction between the negatively charged TW surface and the cationic MB dye molecules [38]. These results demonstrated that $\mathrm{pH}$ had little effect on the capacity of the TW:DO system, indicating that the system has good potential for practical use. 


\subsection{Equilibrium modelling}

\subsubsection{Langmuir Isotherm}

221 The Langmuir isotherm assumes that the surface of the adsorbent is homogeneous, the

222 adsorption energy is constant over all sites and each site can accommodate only one molecule

223 or atom [39]. The Langmuir adsorption isotherm is given as [40]:

$224 q_{e}=\frac{q_{\max } b C_{e}}{1+b C_{e}}$

225 where $q_{\max }(\mathrm{mg} / \mathrm{g})$ and $b\left(\mathrm{dm}^{3} / \mathrm{mg}\right)$ are Langmuir constants associated with the capacity and 226 energy of adsorption.

227 The fundamental characteristics of the Langmuir isotherm can be expressed by a 228 dimensionless separation factor, $R_{\mathrm{L}}$, defined by:

$$
R_{L}=\frac{1}{1+\left(q_{\max } \times b\right) C_{o}}
$$

230 The $R_{L}$ parameter indicates the shape of the isotherm as follows: $R_{L}>1$, unfavourable; $R_{L}=1$,

231 linear; $0<R_{L}<1$, favourable; $R_{L}=0$, irreversible.

\subsubsection{Freundlich Isotherm}

233 The Freundlich isotherm explains a particular phenomenon when the adsorption takes place

234 on a heterogeneous surface [41]. The Freundlich isotherm model is given in Eq. 9:

$235 q_{e}=K_{F} C_{e}^{n}$

236 where $K_{\mathrm{F}}$ and $n$ are the Freundlich constants.

237 The Langmuir and Freundlich isotherm constants obtained from non-linear regression fitting 238 are revealed in Table 2. The Langmuir and Freundlich isotherms were able to represent 239 adsorption of copper ions and methylene blue by both materials in different systems (Figure 3

240 \& 4). The adsorption capacity of DO for $\mathrm{Cu}$ is significantly higher than TW and the trend is 
reversed for MB. It can also be observed that the combination of TW and DO adsorbents will reduce the adsorption capacity towards $\mathrm{Cu}$, while increasing the $\mathrm{MB}$ adsorption capacity (Table 2). In general, the sorption capacities were higher for $\mathrm{MB}$ than $\mathrm{Cu}$, which may be due to the isotherm experiment being carried out without any $\mathrm{pH}$ adjustment. The dimensionless separation factor $\left(R_{\mathrm{L}}\right)$ values were close to zero in all cases. This indicates that the adsorption processes of $\mathrm{Cu}$ ad $\mathrm{MB}$ were favourable at the investigated conditions. The $R_{\mathrm{L}}$ values approached zero when TW:DO systems were used demonstrating that the uptake of the $\mathrm{Cu}$ and MB in these systems was more favourable. The Freundlich constant, $n$ values in the range of 1.061-3.764 confirmed the process is classified as favourable adsorption [42]. The closer $1 / n$ is to zero, the greater the heterogeneity of the adsorbent [43].

\subsection{Surface Characteristics of TW and Dolomite}

\subsubsection{SEM and EDX}

The SEM images of the TW and DO samples before and after adsorption of $\mathrm{Cu}$ and $\mathrm{MB}$ are shown in (Figure 5); experimental conditions: $C_{\mathrm{o}}: \mathrm{MB}=120$ at $\mathrm{pH} 7$ and $\mathrm{Cu}=200$ at $\mathrm{pH} 4.4$ and 6 hrs contact time). From Figure 5 (b) and (c), it can be noticed the formation of crystals at the surface of the DO sample after adsorption with $\mathrm{Cu}$ and $\mathrm{MB}$. The presence of $\mathrm{CuCO}_{3}$ is confirmed with the presence of small and abundant crystals on the surface of DO. The development of crystals in the case of the DO- MB sample also suggests the implication of surface precipitation in the case of MB removal by DO. Similar processes were identified by Walker et al. with the removal of $\mathrm{Cu}^{2+}$ by half charred dolomite where surface complexation and precipitation were identified as the main removal route (See Figure 6 (a)) [25]. Surface precipitation of dye was reported in other studies and accounted for nearly $70 \%$ of dye removal when using lime treatment [44]. For the TW material, very little changes were observed between the samples before and after adsorption of $\mathrm{MB}$ and $\mathrm{Cu}$. The absence of obvious surface structure change indicates that no surface precipitation is involved in the 
removal of both pollutants by TW. The metal ions and dye molecules may bound to the active sites of the biosorbent through electrostatic attraction or hydrogen bonding (Figure 6

(b)). Heavy metals removal by TW is very often accounted to chemisorption while dyes

removal by biosorbents or activated carbon is mainly described through physisorption with minor contribution from chemisorption mechanisms [27, 45]. Table 3 presents the EDX results obtained for the exhausted adsorbents after kinetic experiments. The area analysed was the one presented in Figure 5, focusing on the crystals formed in the case of DO-Cu or DO-MB or on the possibly larger area for the TW-Cu and TW-MB. The thin carbon layer required in the technique shifted all the results obtained for the $\mathrm{C}$ content. However, it can be seen that TW samples are carbon rich as expected and DO contains a substantial amount of $\mathrm{C}$, partly accounted for the $\mathrm{CO}_{3}{ }^{2-}$ groups. The EDX method shows that $\mathrm{Cu}$ is present in the crystals formed at the surface of DO confirming the surface precipitation phenomenon. The presence of sulphur is probably due to the sulphate groups present in the $\mathrm{Cu}$ salt used in the experiment. The EDX technique cannot differentiate between the crystals formed and those in the DO structure. However, due to the experimental conditions, the nature of the copper crystals precipitated are identified as copper hydroxide crystals $\mathrm{Cu}(\mathrm{OH})_{2}$ with potential existence of sulphate or carbonate groups [46]. The blue macroscopic colour of the DO sample after adsorption of copper confirms this identification. In the case of MB adsorption onto DO, the relatively high amount of sulphur can be accounted to the sulphur atoms present in the MB molecule. As the analysis area is focusing only on the crystals visible in Figure 5 (c), the value of nearly $7 \%$ sulphur has to be balanced. Regarding the $\mathrm{TW}-\mathrm{Cu}$ sample, the presence of $4.3 \% \mathrm{Cu}$ at the surface of the sample is equivalent to $43 \mathrm{mg} / \mathrm{g}$ of $\mathrm{Cu}$ adsorption capacity, which is very close to the adsorption capacity calculated in the kinetic experiments (Table 1). The EDX analysis in the present case was carried out over the total surface of the sample from Figure 5 (e) as no surface precipitation was noticed. The very low content of 
291 sulphur on the TW-Cu sample indicates that the sulphate groups from the copper salt are not 292 adsorbed by the biosorbents. The copper sorption onto the TW surface is therefore very 293 selective. The higher content of sulphur on the surface of the TW-MB sample confirms the 294 adsorption of MB. The EDX technique confirmed the precipitation of both $\mathrm{Cu}$ and MB onto 295 the surface of DO and suggested that the sorption of these pollutants onto TW was either due 296 to chemisorption or physisorption.

\subsubsection{FTIR analysis}

298 Figure 7 illustrates the FTIR analysis of the DO samples before and after adsorption of MB

299 and $\mathrm{Cu}$. The spectrum of the DO sample shows several peaks around $1400 \mathrm{~cm}^{-1}$ which are 300 related to the $\mathrm{CO}_{3}{ }^{2-}$ groups and are attributed to the $\mathrm{C}-\mathrm{O}$ bonds present in the sample [26].

301 Bands around $2500 \mathrm{~cm}^{-1}$ are assigned to water molecules bonded to the sample [36]. The net 302 peaks detected after the adsorption of $\mathrm{MB}$ found around $3414 \mathrm{~cm}^{-1}$ are attributed to $\mathrm{OH}^{-}$ 303 bonds and thus show the hydration of the DO sample and possible links with MB molecules 304 through chemisorption. The relatively high peak at $3430 \mathrm{~cm}^{-1}$ confirms the presence of hydroxyl groups and the formation of $\mathrm{Cu}(\mathrm{OH})_{2}$ complexes. A sharp peak observable at 714 $\mathrm{cm}^{-1}$ after $\mathrm{Cu}$ sorption was also noticed by Ippolito et al. and attributed to the presence of

$307 \mathrm{CaO}$ [47]. The formation of complexes in the form of $\mathrm{Ca} / \mathrm{Cu}-(\mathrm{OH})_{\mathrm{x}}$ is thus highly probable. A 308 partial ion-exchange mechanism between $\mathrm{Ca}^{2+}$ and $\mathrm{Cu}^{2+}$ in the removal of copper from 309 wastewater was also reported by Walker et al. [25]. The FTIR analysis for the TW sample 310 shown in Figure 8, demonstrated major peaks indicating many functional groups such as $311-\mathrm{NH}_{2}$ and $-\mathrm{OH}$ groups of proteins and glucose; $-\mathrm{CH}$ stretching and $>\mathrm{C}=\mathrm{O}$ ester stretching 312 vibration of triglycerides; this stretching mode conjugated with the $\mathrm{NH}_{2}$ (amide 1 band) [27].

313 After MB adsorption onto TW two main peaks can be seen at 1383 and $1337 \mathrm{~cm}^{-1}$ and most 314 of the peaks already present are enhanced. The FTIR peaks characteristic of MB molecules overlap with peaks from the TW sample as most chemical groups present in MB are present 
316 in TW. The broad peak visible around $3230-3270 \mathrm{~cm}^{-1}$ is linked to the $\mathrm{N}-\mathrm{H}$ bonding from

317 MB. The peaks around 1737 and $1160 \mathrm{~cm}^{-1}$ account for the sulphate groups and are naturally

318 present on the TW sample [48]. It is thus interesting to note that after $\mathrm{Cu}$ adsorption this peak

319 is relatively high, thus indicating a sorption of the sulphate groups from the copper salt as

320 well. Negatively charged ions are necessary to counter-balance the sorption of $\mathrm{Cu}^{2+}$ onto $\mathrm{TW}$,

321 also $\mathrm{SO}_{4}{ }^{2-}$ is involved in this process. The sorption of both anions and cations is

322 characteristics of physisorption where both ions co-habit in the diffuse layer [49]. EDX

323 analysis coupled with FTIR investigation showed that surface complexation was the main

324 route of removal for $\mathrm{Cu}$ and $\mathrm{MB}$ by $\mathrm{DO}$. Using data from the $\mathrm{pH}$ study it can be concluded

325 that physisorption was responsible for most of $\mathrm{Cu}$ and $\mathrm{MB}$ adsorption onto $\mathrm{TW}$ even if

326 chemisorption was also contributing to the removal of MB by TW.

327 3.6. Comparison of adsorption capacity with composite adsorbents

328 A comparison was carried out between the results of the adsorption capacities of tea waste and dolomite multi-adsorbent system dyes and chemically prepared composite adsorbents towards copper ions and methylene blue (Table 4). Ignoring the different experimental conditions used, it can be seen that the adsorption capacities obtained in this study are comparable with those reported by other researchers. This indicates that tea waste and dolomite multi-adsorbents can be classified as one of the effective adsorption systems for this purpose. The two substances in this investigation were physically mixed without any chemical modifications. Once more, this implies that environmentally friendly composite adsorbents can be produced at low cost and very little effort without any chemical alterations. 
342 The selectivity of tea waste and dolomite for copper and methylene blue and the influence of

343 contact time, solution $\mathrm{pH}$ and initial pollutant concentration on adsorption capacities was

344 examined. The adsorption kinetics could be explained by the pseudo-second-order model.

345 The maximum removal capacity of $\mathrm{Cu}$ onto both adsorbents was achieved at $\mathrm{pH}=4.5$, while

$346 \mathrm{MB}$ was optimally removed over the $\mathrm{pH}$ range studied with removal percentages of over

$34790 \%$. The present investigation indicated that tea waste and dolomite can concurrently be

348 effectively used to remove copper and methylene blue from aqueous solution. Further studies

349 are required to examine the effect of the chemistry of solution and the design and scale-up of

350 fixed-bed adsorption columns.

351

352

353

354

355

356

357

358

359

360

361

362

363

364

365 
367 [1] A.B. Albadarin, C. Mangwandi, G.M. Walker, S.J. Allen, M.N. Ahmad, Biosorption

368 characteristics of sawdust for the removal of Cd(II) Ions: Mechanism and thermodynamic

[2] G. Zhao, H. Zhang, Q. Fan, X. Ren, J. Li, Y. Chen, X. Wang, Sorption of copper(II) onto super-adsorbent of bentonite-polyacrylamide composites, Journal of Hazardous Materials, 173 (2010) 661-668.

[3] P.A. Brown, J.M. Brown, S.J. Allen, The application of kudzu as a medium for the adsorption of heavy metals from dilute aqueous wastestreams, Bioresource Technology, 78 (2001) 195-201.

[4] Maria Visa, Cristina Bogatu, A. Duta, Simultaneous adsorption of dyes and heavy metals from multicomponent solutions using fly ash, Applied Surface Science, 256 (2010) 54865491.

[5] B. Noroozi, G.A. Sorial, Applicable models for multi-component adsorption of dyes: A review, Journal of Environmental Sciences, 25 (2013) 419-429.

[6] George Z. Kyzas, Nikolaos K. Lazaridis, M. Kostoglou, On the simultaneous adsorption of a reactive dye and hexavalent chromium from aqueous solutions onto grafted chitosan, Journal of Colloid and Interface Science, 407 (2013) 432-441.

[7] Y.S. Al-Degs, A.H. El-Sheikh, M.A. Al-Ghouti, B. Hemmateenejad, G.M. Walker, Solidphase extraction and simultaneous determination of trace amounts of sulphonated and azo sulphonated dyes using microemulsion-modified-zeolite and multivariate calibration, Talanta, 75 (2008) 904-915.

[8] S.J. Allen, G. McKay, J.F. Porter, Adsorption isotherm models for basic dye adsorption by peat in single and binary component systems, Journal of Colloid and Interface Science, 280 (2004) 322-333.

[9] G.M. Walker, L. Hansen, J.-A. Hanna, S.J. Allen, Kinetics of a reactive dye adsorption onto dolomitic sorbents, Water Research, 37 (2003) 2081-2089.

[10] Pranay A Raut, Monal Dutta, Sonali Sengupta, J.K. Basu, Alumina-carbon composite as an effective adsorbent for removal of Methylene Blue and Alizarin Red-s from aqueous solution, Indian Journal of Chemical Technology, 20 (2013) 15-20.

[11] Yuttasak Chammui, Ponlayuth Sooksamiti, Wimol Naksata, Sakdiphon Thiansem, O.-a. Arqueropanyo, Removal of arsenic from aqueous solution by adsorption on Leonardite, Chemical Engineering Journal, 240 (2014) 202-210.

[12] Yahya S. Al-Degs, Amjad H. El-Sheikh, Mohammad A. Al-Ghouti, Bahram Hemmateenejad, G.M. Walker, Solid-phase extraction and simultaneous determination of trace amounts of sulphonated and azo sulphonated dyes using microemulsion-modifiedzeolite and multivariate calibration, Talanta, 75 (2008) 904-915.

[13] L. Wang, A. Wang, Adsorption characteristics of Congo Red onto the chitosan/montmorillonite nanocomposite, Journal of Hazardous Materials, 147 (2007) 979985.

[14] M.R. Awual, M. Ismael, T. Yaita, S.A. El-Safty, H. Shiwaku, Y. Okamoto, S. Suzuki, Trace copper(II) ions detection and removal from water using novel ligand modified composite adsorbent, Chemical Engineering Journal, 222 (2013) 67-76.

[15] A. Ely, M. Baudu, M.O.S.A.O. Kankou, J.-P. Basly, Copper and nitrophenol removal by low cost alginate/Mauritanian clay composite beads, Chemical Engineering Journal, 178 (2011) 168-174.

[16] M. Visa, L. Isac, A. Duta, Fly ash-activated carbon powder composites for dyes and heavy metals removal, Advanced Materials Research, 79-82 (2009) 243-246. 
414 [17] K.Y. Ho, G. McKay, K.L. Yeung, Selective adsorbents from ordered mesoporous silica, 415 Langmuir, 19 (2003) 3019-3024.

416 [18] A.A. Khouloud, E.W. Dale, Prediction of adsorption from multicomponent solutions by 417 acti-vated carbon using single-solute parameters. Part II - proposed equation, AAPS 418 PharmSciTech, 3 (2002) 1-8.

419 [19] K.K.H. Choy, J.F. Porter, G. McKay, Intraparticle diffusion in single and 420 multicomponent acid dye adsorption from wastewater onto carbon, Chemical Engineering 421 Journal, 103 (2004) 133-145.

422 [20] P.V. Brady, J.L. Krumhansl, H.W. Papenguth, Surface complexation clues to dolomite 423 growth, Geochimica et Cosmochimica Acta, 60 (1996) 727-731.

[21] S.J. Allen, B. Koumanova, Decolourisation of water/wastewaterusing adsorption: review, Journal of the University of Chemical Technology and Metallurgy, 40 (2005) 175192.

[22] N.S. Mokgalaka, R.I. McCrindle, B.M. Botha, Multielement analysis of tea leaves by inductively coupled plasma optical emission spectro metry using slurry nebulization, Journal of Analytical Atomic Spectrometry, 19 (2004) 1375-1378.

430 [23] B.H. Hameed, Spent tea leaves: A new non-conventional and low-cost adsorbent for removal of basic dye from aqueous solutions, Journal of Hazardous Materials, 161 (2009) 753-759.

433 [24] C. Mangwandi, A.B. Albadarin, L. JiangTao, S. Allen, G.M. Walker, Development of a 434 value-added soil conditioner from high shear co-granulation of organic waste and limestone 435 powder, Powder Technology, 252 (2014) 33-41.

436 [25] G.M. Walker, G. Connor, S.J. Allen, Copper (II) Removal onto Dolomitic Sorbents, 437 Chemical Engineering Research and Design, 82 (2004) 961-966.

438 [26] A.B. Albadarin, C. Mangwandi, A.a.H. Al-Muhtaseb, G.M. Walker, S.J. Allen, M.N.M. 439 Ahmad, Kinetic and thermodynamics of chromium ions adsorption onto low-cost dolomite 440 adsorbent, Chemical Engineering Journal, 179 (2012) 193-202.

[27] A.B. Albadarin, C. Mangwandi, G.M. Walker, S.J. Allen, M.N.M. Ahmad, M. Khraisheh, Influence of solution chemistry on $\mathrm{Cr}(\mathrm{VI})$ reduction and complexation onto datepits/tea-waste biomaterials, Journal of Environmental Management, 114 (2013) 190-201.

[28] K.A.G. Gusmão, L.V.A. Gurgel, T.M.S. Melo, L.F. Gil, Adsorption studies of methylene blue and gentian violet on sugarcane bagasse modified with EDTA dianhydride (EDTAD) in aqueous solutions: Kinetic and equilibrium aspects, Journal of Environmental Management, 118 (2013) 135-143.

448 [29] C. Moreno-Castilla, Adsorption of organic molecules from aqueous solution on carbon materials, Carbon, 42 (2004) 83-94.

[30] S. Lagergren, Zur theorie der sogenannten adsorption gelöster stoffe KungligaSvenska Vetenskapsakademiens, Handlingar, 24 (1898) 1-39.

[31] Y.S. Ho, G. McKay, Pseudo-second order model for sorption process, Process Biochemistry 34 (1999) 451-465.

454 [32] Weifeng Liu, Jian Zhang, Cheng Cheng, Guipeng Tian, C. Zhang, Ultrasonic-assisted sodium hypochlorite oxidation of activated carbons for enhanced removal of $\mathrm{Co}$ (II) from aqueous solutions Original Research Article, Chemical Engineering Journal, 175 (2011) 2432. removal by chitosan-coated sludge derived from water treatment plant, International Journal of Environmental Science and Development, 4 (2013) 545-550. adsorption of methylene blue by a magnetic graphene-carbon nanotube composite, Applied Surface Science, 290 (2014) 116-124. 
[35] M.M. Ayad, A. Abu El-Nasr, J. Stejskal, Kinetics and isotherm studies of methylene blue adsorption onto polyaniline nanotubes base/silica composite, Journal of Industrial and Engineering Chemistry, 18 (2012) 1964-1969. [36] Yoann Glocheux, Martín Méndez Pasarín, Ahmad B. Albadarin, Stephen J. Allen, G.M. Walker, Removal of arsenic from groundwater by adsorption onto an acidified laterite byproduct, Chemical Engineering Journal, 228 (2013) 565-574. [37] M.A. Hossain, H.H. Ngo, W.S. Guo, T. Setiadi, Adsorption and desorption of copper(II) ions onto garden grass, Bioresource Technology, 121 (2012) 386-395.

[38] E.N. El Qada, S.J. Allen, G.M. Walker, Adsorption of Methylene Blue onto activated carbon produced from steam activated bituminous coal: A study of equilibrium adsorption isotherm, Chemical Engineering Journal, 124 (2006) 103-110.

475 [39] I. Langmuir, The adsorption of gases on plane surfaces of glass, mica and platinum, 40 476 (1918) 1361-1403.

477 [40] I. Langmuir, The constitution and fundamental properties of solids and liquids, Journal 478 of the American Chemical Society 38 (1916) 2221-2295.

479 [41] H.M.F. Freundlich, Over the adsorption in solution, The Journal of Physical Chemistry 48057 (1906) 385-471.

481 [42] Samar K. Theydan, M.J. Ahmed, Adsorption of methylene blue onto biomass-based 482 activated carbon by $\mathrm{FeCl}_{3}$ activation: Equilibrium, kinetics, and thermodynamic studies, 483 Journal of Analytical and Applied Pyrolysis, 97 (2012) 116-122.

484 [43] A. Duffy, G.M. Walker, S.J. Allen, Investigations on the adsorption of acidic gases using activated dolomite, Chemical Engineering Journal, 117 (2006) 239-244.

[44] V. Vimonses, B. Jin, C.W.K. Chow, Insight into removal kinetic and mechanisms of anionic dye by calcined clay materials and lime, Journal of Hazardous Materials, 177 (2010) 420-427.

[45] M.A. Al-Ghouti, J. Li, Y. Salamh, N. Al-Laqtah, G. Walker, M.N.M. Ahmad, Adsorption mechanisms of removing heavy metals and dyes from aqueous solution using date pits solid adsorbent, Journal of Hazardous Materials, 176 (2010) 510-520.

[46] P. Papadopoulos, D.L. Rowell, The reactions of copper and zinc with calcium carbonate surfaces, European Journal of Soil Science, 40 (1989) 39-48.

[47] J.A. Ippolito, D.G. Strawn, K.G. Scheckel, J.M. Novak, M. Ahmedna, M.A. Niandou, Macroscopic and molecular investigations of copper sorption by a steam-activated biochar, Journal of Environmental Quality, 41 (2012) 1150-1156.

[48] E. Malkoc, Y. Nuhoglu, Fixed bed studies for the sorption of chromium(VI) onto tea factory waste, Chemical Engineering Science, 61 (2006) 4363-4372. 
1 Preliminary investigation of mixed adsorbents for the removal of copper and methylene

blue from aqueous solutions

5 Ahmad B. Albadarin ${ }^{1,2 *}$, Jiabin $\mathrm{Mo}^{1}$, Yoann Glocheux ${ }^{1}$, Stephen Allen ${ }^{1}$, Gavin Walker ${ }^{1,2}$,

$9{ }^{1}$ Materials Surface Science Institute, Department of Chemical and Environmental Sciences,

10 University of Limerick, Ireland

$11{ }^{2}$ School of Chemistry and Chemical Engineering, Queen's University Belfast, Belfast BT9

$125 A G$, Northern Ireland, UK. 


\section{Abstract}

27 With most recent studies being focused on the development of advanced chemical 28 adsorbents, this paper investigates the possibility of using two natural low-cost materials for 29 selective adsorption. Multi-adsorbent systems containing tea waste (TW) and dolomite (DO) 30 have been tested for their effectiveness in the removal of copper and methylene blue from 31 aqueous solutions. The effects of contact time, solution $\mathrm{pH}$ and adsorption isotherms on the 32 sorption behaviour were investigated. The Langmuir and Freundlich isotherms adequately 33 described the adsorption of copper ions and methylene blue by both materials in different 34 systems. The highest adsorption capacities for $\mathrm{Cu}$ and $\mathrm{MB}$ were calculated as $237.7 \mathrm{mg} / \mathrm{g}$ at $35 \mathrm{pH} 4.5$ and $150.4 \mathrm{mg} / \mathrm{g}$ at $\mathrm{pH} 7$ for DO and TW:DO respectively. Tea waste and dolomite 36 were characterized by Fourier transform infrared spectroscopy, scanning electron microscopy 37 and Energy dispersive X-ray analysis. The removal of $\mathrm{Cu}$ and $\mathrm{MB}$ by dolomite was mainly 38 via surface complexation while physisorption was responsible for most of the $\mathrm{Cu}$ and $\mathrm{MB}$

39 adsorption onto tea waste. Identifying the fundamental mechanisms and behaviour is key to 40 the development of practical multi-adsorbent packed columns.

42 Keywords: Multi-adsorbents; Wastewater; Adsorption technique; Heavy metals; Dyes 


\section{Introduction}

52 Dyes (very frequently methylene blue and methyl orange) and heavy metals (copper,

53 cadmium and nickel mostly from the organo-metallic dyes) are dangerous pollutants found in

54 large quantities in wastewaters from textile and paper industries. It is known that heavy

55 metals are toxic and non-biodegradable [1,2]. Heavy metals have many environmental

56 issues such as animal and plant death, reduced rates of reproduction and the decrease of

57 ecosystem diversity [3]. While dyes are difficult to treat as the colour tends to hold strong

58 even after the conventional removal processes [4]. There are more than 100,000

59 commercially available dyes with over 700,000 tons produced annually [5]. The presence of

60 some of these dyes even in very small amounts i.e. $<1 \mathrm{mg} \cdot \mathrm{dm}^{\square 3}$ is undesirable $[6,7]$. Dyes-

61 Heavy metal loaded wastewaters are highly coloured, have a fluctuating $\mathrm{pH}$ and regularly

62 contain large amounts of suspended oils. Dyes and heavy metals find their way into the

63 environment, primarily dissolved or suspended in water everyday [8] and create serious

64 damage to the environment by changing the biological life balance in rivers and lakes $[9,10]$.

65 Adsorption is a well-established and powerful practice for the removal of dyes and heavy

66 metal pollutants from wastewaters. For these reasons, thousands of investigations have used

67 uncountable adsorbents to remove heavy metals [11] or dyes [12]. Most of these studies focus

68 on single-component aqueous solutions and recently, more research papers have been

69 published dealing with the adsorption of dyes and metals in multi-component aqueous

70 systems [6]. Also, composite adsorbents have been established to adsorb dyes and heavy

71 metals from wastewater such as chitosan/montmorillonite composites [13-15] and fly

72 ash/activated carbon [16]. In previous studies, composite materials were used to selectively

73 adsorb a particular pollutant. Ho and co-workers proved that amino functionalized silica

74 solids can selectively adsorb dye anthraquinone blue in the presence of methylene blue,

75 while, from the same dye mixture, carboxy-functionalized materials adsorb methylene blue 
76 selectively [17]. Prediction of multicomponent adsorption is still one of the most challenging

77 problems in the adsorption field [18]. There is little data available to provide more

78 understanding about the interactions between adsorbents and developing design models for

79 such practical systems is very important [19]. This is the case for many composite materials

80 as well as adsorption processes with multi-adsorbate and multi-adsorbent systems. Dolomite,

81 with a structure of alternative layers of calcite and magnesite, is a potential inexpensive and

82 readily available adsorbent [20]. Many studies showed that dolomite and charred dolomite

83 have the potential to act as adsorbents for reactive dyes and heavy metals [21]. Tea,

84 processed leaves from Camellia sinensis species, is the second most common drink being

85 consumed after water with an average daily drinking of 20 billion cups. The producers of

86 making tea drinks face a problem in disposing of the spent tea leaves after the extraction [22,

87 23]. The feasibility of using the richly available solid waste, spent tea leaves, for the removal

88 of heavy metals and dyes has also been extensively investigated [24]. A good understanding

89 of the effect of adsorbent-adsorbent interactions on selective adsorption is essential as a

90 foundation for selecting the best adsorbent and employing it in an optimal way. Hence, the

91 aim of this research is to clarify the chemical and physical interferences between the two

92 materials, namely tea waste and dolomite, when used for the removal of copper and

93 methylene blue from aqueous solutions. In this paper, the term adsorption will refer to

94 biosorption onto tea waste (TW) and adsorption onto dolomite (DO). Copper ions and

95 methylene blue dye adsorption onto tea waste and dolomite using different factors, such as

96 reaction contact time and $\mathrm{pH}$ of solution as well as initial metal and dye concentration on

97 selective adsorption was examined. Recognizing the fundamental mechanisms and behaviour

98 would be useful for practical multi-adsorbent packed columns.

99

100 


\section{Materials and Methods}

\subsection{Adsorbents and adsorbates}

103 The two low cost materials used in this experiment were tea waste (TW) biosorbent and 104 dolomite (DO) adsorbent. Fine Dolomite $\left(\mathrm{d}_{\mathrm{P}}<50 \mu \mathrm{m}\right)$ was supplied by Killwaughter

105 Chemical Company, UK. The typical chemical composition of the dolomite in the deposit 106 was $44 \% \mathrm{MgCO}_{3}$ and $53 \% \mathrm{CaCO}_{3}$ (obtained by $\mathrm{XRD}$ analysis) [25]. The tea waste

107 biosorbent was collected from Queen's University cafeteria; it was washed several times with 108 hot water and dried in a conventional oven at $110{ }^{\circ} \mathrm{C}$. The two adsorbents were 109 comprehensively characterized in previous investigations [26, 27]. Copper(II) and Methylene

110 Blue (MB) stock solutions were prepared by dissolving known amounts of $\mathrm{CuSO}_{4} \cdot 5 \mathrm{H}_{2} \mathrm{O}$ and $111 \mathrm{MB}$ in deionised water. The stock solutions were then diluted to get various initial 112 concentrations. All chemicals were purchased from Sigma Aldrich UK.

\section{2.2. Adsorption Experiment}

114 To investigate the influence of $\mathrm{pH}$ on $\mathrm{Cu}(\mathrm{II})$ and $\mathrm{MB}$ adsorption onto $\mathrm{TW}$ and $\mathrm{DO}$, six sets of 115 experiments were prepared: $\mathrm{Cu}(\mathrm{II})$ or $\mathrm{MB}$ with $\mathrm{TW}$ biosorbent; $\mathrm{Cu}(\mathrm{II})$ or $\mathrm{MB}$ with $\mathrm{DO}$ 116 adsorbent and $\mathrm{Cu}(\mathrm{II})$ or MB with a mixture of 1:1 TW:DO (w/w\%). Samples of $25 \mathrm{~cm}^{3}$ of 117 adsorbate solutions with $C_{\mathrm{o}}=120$ and $100 \mathrm{mg} / \mathrm{dm}^{3}$ of $\mathrm{Cu}$ and $\mathrm{MB}$, respectively, were 118 adjusted to different $\mathrm{pH}$ values: $2-11$. The same procedures were performed to study the 119 effect of contact time and adsorption isotherms. The initial concentrations of $\mathrm{Cu}$ (II) for the 120 contact time studies was $200 \mathrm{mg} / \mathrm{dm}^{3}$ and for MB it was $120 \mathrm{mg} / \mathrm{dm}^{3}$. For the adsorption

121 isotherm studies, a concentration of: $C_{\mathrm{o}}=10-100 \mathrm{mg} / \mathrm{dm}^{3}$ for $\mathrm{Cu}(\mathrm{II})$ and $C_{\mathrm{o}}=10-75 \mathrm{mg} / \mathrm{dm}^{3}$

122 for $\mathrm{MB}$ were used. An adsorbent dose of $1 \mathrm{~g} / \mathrm{dm}^{3}$ was used for all experiments at room 123 temperature $\left(\sim 20^{\circ} \mathrm{C}\right)$ and a contact time of 4 days to ensure reaching the equilibrium. There 124 were no $\mathrm{pH}$ adjustments for contact time and isotherm experiments, so the experimental 125 processes are more environmental friendly. The concentrations of $\mathrm{Cu}(\mathrm{II})$ and $\mathrm{MB}$ were 
126 analysed using an ICP $\square$ OES Thermo Scientific IRIS and UV/Vis spectrophotometer (Perkin

127 Elmer LAMBDA 25, UK), respectively. The amount of $\mathrm{Cu}(\mathrm{II})$ and $\mathrm{MB}$ adsorbed per unit

128 mass of adsorbent $q$ in $(\mathrm{mg} / \mathrm{g})$ and removal percentage were calculated using Eq. (1) and Eq.

129 (2):

130 The percentage removal $=\left[1-\frac{C_{e}}{C_{o}}\right] \times 100 \%$

$131 q=\left[\frac{C_{o}-C_{e}}{M}\right] \times V$

132 Where $C_{\mathrm{o}}$ and $C_{\mathrm{e}}(\mathrm{mg} / \mathrm{L})$ are the concentration of adsorbate at initial and equilibrium,

133 respectively, $M$ is the mass of adsorbent $(\mathrm{g})$ and $V$ is the volume $\left(\mathrm{dm}^{3}\right)$.

\section{$134 \quad$ 2.3. Infrared and SEM measurement}

135 The FT-IR analyses for TW and DO surfaces before and after $\mathrm{Cu}(\mathrm{II})$ and $\mathrm{MB}$ adsorption were

136 carried out on a Perkin Elmer Spectrum 100 within the range of $400-4000 \mathrm{~cm}^{-1}$. For the

137 SEM analysis and Energy dispersive X-ray (EDX) analysis, TW and DO samples were

138 coated with carbon and vacuumed (5-10 $\mathrm{min}$ ) for electron reflection prior to analysis on a

139 JEOL-JSM 6400 scanning microscope.

140

141

142

143

144

145

146 


\section{3. Results and Discussion}

\section{$148 \quad 3.1$. Effect of contact time}

149 Figures S1 (a) and (b) are the plots of $\mathrm{Cu}(\mathrm{II})$ and $\mathrm{MB}$ removal against time for TW and DO 150 materials, respectively. It can been seen that $\mathrm{Cu}(\mathrm{II})$ and $\mathrm{MB}$ were almost completely

151 removed by dolomite and tea waste after $6 \mathrm{hrs}$ at room temperature $\left(20^{\circ} \mathrm{C}\right)$. The adsorption of

$152 \mathrm{Cu}(\mathrm{II})$ and $\mathrm{MB}$ dye was fast in the initial stage due to the large number of available binding 153 sites, resulting in a concentration gradient [28]. The removal rate gradually declined with

154 time until equilibrium was achieved. The maximum removal efficiencies of copper ions and $155 \mathrm{MB}$ onto TW and DO were approx. $90 \%$ at $\mathrm{pH}$ of 5-7. The adsorption capacities of $\mathrm{Cu}$ (II) 156 and MB were reduced when the two materials were mixed together; this reduction was more 157 significant in the case of $\mathrm{Cu}(\mathrm{II})$. The adsorption capacity of the mixed adsorbent (TW:DO) 158 was reduced to approx. $45 \%$ and $85 \%$ for $\mathrm{Cu}$ and $\mathrm{MB}$, respectively. This reduction is 159 attributed to the change in the sorbent and solution properties such as $\mathrm{pH}_{\mathrm{PZC}}$ and $\mathrm{pH}_{\text {equilibrium }}$ 160 [29]. However, results indicate that these pollutants can still be efficiently removed with high 161 selectivity onto the mixed adsorbents.

\subsection{Kinetics Modelling}

163 The adsorption mechanism can be investigated using various adsorption kinetics models. 164 The pseudo first- [30] and pseudo second-order [31] models (Eq. 3 and Eq. 4) have been 165 employed to examine the experimental data for the adsorption of $\mathrm{Cu}(\mathrm{II})$ and $\mathrm{MB}$ by nonlinear 166 regression. The pseudo first-order model equation is given as follow:

$167 \quad q_{t}=q_{e}\left(1-e^{-k_{1} t}\right)$

168 The pseudo second-order equation is given as;

$169 \quad q_{t}=\frac{k_{2} q_{e}^{2}}{\left(1+k_{2} q_{e} t\right)} t$

170 The second-order rate constants were used to calculate the initial sorption rate given by: 
$171 h=k_{2} q_{e}^{2}$

172 where $k_{1}(1 / \mathrm{min})$ and $k_{2}(\mathrm{~g} / \mathrm{mg} \mathrm{min})$ are the rate constants for first order and second-order 173 models.

174 The plots of $q_{\mathrm{t}}$ versus $t$ and values of the constants of kinetic models obtained from the plots

175 are given in Figure 1 and Table 1. From Table 1, the pseudo first- and pseudo second-order

176 models fit the kinetic data with adequate accuracy $\left(R^{2}>0.897\right)$. However, the experimental

177 data demonstrated more agreement with the pseudo second-order model in terms of closer

$178 q_{\mathrm{e}, \text { cal }}$ values to $q_{\mathrm{e}, \mathrm{exp}}$ and higher correlation coefficients than the pseudo first-order model.

179 This indicates that the chemical adsorption was the main control process for the TW and DO

180 materials and the uptake capacity is proportional to the number of active sites [32]. Similar

181 trends were reported for the removal of copper onto chitosan-coated sludge [33] and

182 methylene blue onto magnetic graphene-carbon nanotube composite and polyaniline

183 nanotubes base/silica [34, 35]. The rate constants $\left(k_{1}\right.$ and $\left.k_{2}\right)$ for both $\mathrm{Cu}(\mathrm{II})$ and $\mathrm{MB}$ sorption

184 onto the TW biosorbent are higher than that for the DO adsorbent. This indicates that it is

185 faster for $\mathrm{Cu}(\mathrm{II})$ and $\mathrm{MB} \square \mathrm{TW}$ systems to reach a specific fractional uptake. Initial

186 adsorption rate $(h)$ values for $\mathrm{Cu}(\mathrm{II})$ and $\mathrm{MB}$ sorption followed the same trends $(\mathrm{Cu}(\mathrm{II})$

187 (89.07 $\square 110.9 \mathrm{mg} / \mathrm{g} \mathrm{min})$ and $\mathrm{MB}(17.56-56.65 \mathrm{mg} / \mathrm{g} \mathrm{min})$. Also, the Elovich equation was

188 used to evaluate the kinetic sorption data. The linear form of the Elovich equation is given in

189 Eq. 6 below:

$190 \quad q_{t}=1 / \beta \ln (\alpha \beta)+1 / \beta \ln (t)$

191 where $\alpha$ is the initial adsorption rate $(\mathrm{mg} / \mathrm{g} \mathrm{min})$, whilst $\beta$ is the extent of surface coverage

$192(\mathrm{~g} / \mathrm{mg})$ and activation energy of the process.

193 As can be seen in Table 1, the initial sorption rate $(\alpha)$ is lower in the case of sorption onto the

194 DO system, similar to that of rate constants and initial sorption rate $(h)$ in the pseudo second- 
195 order model. The Elovich equation did not fit the experimental data very well with the

196 regression coefficient, $R^{2}$, within $0.659-0.877$, suggesting that sorption systems of this study

197 are maybe homogeneous.

\section{3.3. Effect of solution $\mathbf{p H}$}

199 The $\mathrm{pH}$ parameter is associated with the adsorption mechanisms onto the adsorbent/biomass 200 surfaces from water and determines the magnitude of the electrostatic charges [36]. From

201 Figure 2, it can be observed that the uptake of $\mathrm{Cu}$ (II) onto the $\mathrm{DO}$ is significantly increased

202 from $39 \%$ of removal at $\mathrm{pH} 2$ to a maximum removal of $89 \%$ at $\mathrm{pH} 4.5$. At this $\mathrm{pH}$ value, the

203 main species of copper are $\mathrm{Cu}$ (II) free ions which are primarily involved in the removal

204 process. With a $\mathrm{pH}$ value greater than 6 , immediate precipitation of copper hydroxide takes

205 place especially for high concentration of $\mathrm{Cu}$ (II) ions hindering the adsorption or biosorption

206 processes [37]. The adsorption capacity of $\mathrm{Cu}(\mathrm{II})$ onto TW was notably lower at $\mathrm{pH} 4.5$ with

207 a maximum percentage removal of $39 \%$ at $\mathrm{pH}$ 5.5. The relatively lower $\mathrm{Cu}$ (II) removal onto

208 TW can be attributed to the surface chemistry properties of TW such as; the surface point of

209 zero charge. The PZC was previously determined to be $\mathrm{pH}=4$ [27] and had an important

210 effect on the equilibrium ( $\mathrm{pH}_{\text {equilibrium }}$ ). For example, the $\mathrm{Cu}(\mathrm{II})$ solution with a $\mathrm{pH}_{\mathrm{o}}=5.5$

211 decreased to $\mathrm{pH}_{\mathrm{eq}}=4.2$ after being put in contact with TW for 4 days. Similar trends were

212 observed for the biosorption of Cd(II) onto sawdust [1]. Also, it was found that the

213 equilibrium $\mathrm{pH}$ for $\mathrm{MB}$ solution at $\mathrm{pH}_{\mathrm{o}}=10$ was reduce to $\mathrm{pH}_{\mathrm{eq}}=8.8$ when using the TW:DO

214 mixed adsorbent. However, MB was efficiently removed by TW over the $\mathrm{pH}$ range studied,

215 which is attributable to the electrostatic attraction between the negatively charged TW surface

216 and the cationic MB dye molecules [38]. These results demonstrated that $\mathrm{pH}$ had little effect

217 on the capacity of the TW:DO system, indicating that the system has good potential for 218 practical use. 


\section{3.4. Equilibrium modelling}

\section{3.4.1. Langmuir Isotherm}

221 The Langmuir isotherm assumes that the surface of the adsorbent is homogeneous, the

222 adsorption energy is constant over all sites and each site can accommodate only one molecule

223 or atom [39]. The Langmuir adsorption isotherm is given as [40]:

$224 q_{e}=\frac{q_{\max } b C_{e}}{1+b C_{e}}$

225 where $q_{\max }(\mathrm{mg} / \mathrm{g})$ and $b\left(\mathrm{dm}^{3} / \mathrm{mg}\right)$ are Langmuir constants associated with the capacity and

226 energy of adsorption.

227 The fundamental characteristics of the Langmuir isotherm can be expressed by a 228 dimensionless separation factor, $R_{\mathrm{L}}$, defined by:

$229 \quad R_{L}=\frac{1}{1+\left(q_{\max } \times b\right) C_{o}}$

230 The $R_{L}$ parameter indicates the shape of the isotherm as follows: $R_{L}>1$, unfavourable; $R_{L}=1$,

231 linear; $0<R_{L}<1$, favourable; $R_{L}=0$, irreversible.

\section{$232 \quad 3.4 .2$. Freundlich Isotherm}

233 The Freundlich isotherm explains a particular phenomenon when the adsorption takes place 234 on a heterogeneous surface [41]. The Freundlich isotherm model is given in Eq. 9:

$235 q_{e}=K_{F} C_{e}^{n}$

236 where $K_{\mathrm{F}}$ and $n$ are the Freundlich constants.

237 The Langmuir and Freundlich isotherm constants obtained from non-linear regression fitting

238 are revealed in Table 2. The Langmuir and Freundlich isotherms were able to represent

239 adsorption of copper ions and methylene blue by both materials in different systems (Figure 3

$240 \& 4)$. The adsorption capacity of DO for $\mathrm{Cu}$ is significantly higher than TW and the trend is 
241 reversed for MB. It can also be observed that the combination of TW and DO adsorbents will

242 reduce the adsorption capacity towards $\mathrm{Cu}$, while increasing the $\mathrm{MB}$ adsorption capacity

243 (Table 2). In general, the sorption capacities were higher for $\mathrm{MB}$ than $\mathrm{Cu}$, which may be due

244 to the isotherm experiment being carried out without any $\mathrm{pH}$ adjustment. The dimensionless

245 separation factor $\left(R_{\mathrm{L}}\right)$ values were close to zero in all cases. This indicates that the adsorption

246 processes of $\mathrm{Cu}$ ad $\mathrm{MB}$ were favourable at the investigated conditions. The $R_{\mathrm{L}}$ values

247 approached zero when TW:DO systems were used demonstrating that the uptake of the $\mathrm{Cu}$

248 and MB in these systems was more favourable. The Freundlich constant, $n$ values in the

249 range of 1.061-3.764 confirmed the process is classified as favourable adsorption [42]. The

250 closer $1 / n$ is to zero, the greater the heterogeneity of the adsorbent [43].

\section{3.5. Surface Characteristics of TW and Dolomite}

\section{3.5.1. SEM and EDX}

253 The SEM images of the TW and DO samples before and after adsorption of $\mathrm{Cu}$ and MB are

254 shown in (Figure 5); experimental conditions: $C_{\mathrm{o}}$ : $\mathrm{MB}=120$ at $\mathrm{pH} 7$ and $\mathrm{Cu}=200$ at $\mathrm{pH} 4.4$

255 and 6 hrs contact time). From Figure 5 (b) and (c), it can be noticed the formation of crystals

256 at the surface of the DO sample after adsorption with $\mathrm{Cu}$ and $\mathrm{MB}$. The presence of $\mathrm{CuCO}_{3}$ is

257 confirmed with the presence of small and abundant crystals on the surface of DO. The

258 development of crystals in the case of the DO-MB sample also suggests the implication of

259 surface precipitation in the case of MB removal by DO. Similar processes were identified by

260 Walker et al. with the removal of $\mathrm{Cu}^{2+}$ by half charred dolomite where surface complexation

261 and precipitation were identified as the main removal route (See Figure 6 (a)) [25]. Surface

262 precipitation of dye was reported in other studies and accounted for nearly $70 \%$ of dye

263 removal when using lime treatment [44]. For the TW material, very little changes were

264 observed between the samples before and after adsorption of $\mathrm{MB}$ and $\mathrm{Cu}$. The absence of

265 obvious surface structure change indicates that no surface precipitation is involved in the 
removal of both pollutants by TW. The metal ions and dye molecules may bound to the active sites of the biosorbent through electrostatic attraction or hydrogen bonding (Figure 6 (b)). Heavy metals removal by TW is very often accounted to chemisorption while dyes removal by biosorbents or activated carbon is mainly described through physisorption with minor contribution from chemisorption mechanisms [27, 45]. Table 3 presents the EDX results obtained for the exhausted adsorbents after kinetic experiments. The area analysed was the one presented in Figure 5, focusing on the crystals formed in the case of DO-Cu or DO-MB or on the possibly larger area for the TW-Cu and TW-MB. The thin carbon layer required in the technique shifted all the results obtained for the $\mathrm{C}$ content. However, it can be seen that TW samples are carbon rich as expected and DO contains a substantial amount of $\mathrm{C}$, partly accounted for the $\mathrm{CO}_{3}{ }^{2-}$ groups. The EDX method shows that $\mathrm{Cu}$ is present in the crystals formed at the surface of DO confirming the surface precipitation phenomenon. The presence of sulphur is probably due to the sulphate groups present in the $\mathrm{Cu}$ salt used in the experiment. The EDX technique cannot differentiate between the crystals formed and those in the DO structure. However, due to the experimental conditions, the nature of the copper crystals precipitated are identified as copper hydroxide crystals $\mathrm{Cu}(\mathrm{OH})_{2}$ with potential existence of sulphate or carbonate groups [46]. The blue macroscopic colour of the DO sample after adsorption of copper confirms this identification. In the case of MB adsorption onto DO, the relatively high amount of sulphur can be accounted to the sulphur atoms present in the MB molecule. As the analysis area is focusing only on the crystals visible in Figure 5 (c), the value of nearly $7 \%$ sulphur has to be balanced. Regarding the TW-Cu sample, the presence of $4.3 \% \mathrm{Cu}$ at the surface of the sample is equivalent to $43 \mathrm{mg} / \mathrm{g}$ of $\mathrm{Cu}$ adsorption capacity, which is very close to the adsorption capacity calculated in the kinetic experiments (Table 1). The EDX analysis in the present case was carried out over the total surface of the sample from Figure 5 (e) as no surface precipitation was noticed. The very low content of 
291 sulphur on the TW-Cu sample indicates that the sulphate groups from the copper salt are not 292 adsorbed by the biosorbents. The copper sorption onto the TW surface is therefore very

293 selective. The higher content of sulphur on the surface of the TW-MB sample confirms the

294 adsorption of MB. The EDX technique confirmed the precipitation of both $\mathrm{Cu}$ and $\mathrm{MB}$ onto

295 the surface of DO and suggested that the sorption of these pollutants onto TW was either due

296 to chemisorption or physisorption.

\section{3.5.2. FTIR analysis}

298 Figure 7 illustrates the FTIR analysis of the DO samples before and after adsorption of MB

299 and $\mathrm{Cu}$. The spectrum of the DO sample shows several peaks around $1400 \mathrm{~cm}^{\square}$ which are 300 related to the $\mathrm{CO}_{3}{ }^{2-}$ groups and are attributed to the $\mathrm{C}-\mathrm{O}$ bonds present in the sample [26].

301 Bands around $2500 \mathrm{~cm}^{-1}$ are assigned to water molecules bonded to the sample [36]. The net 302 peaks detected after the adsorption of $\mathrm{MB}$ found around $3414 \mathrm{~cm}^{-1}$ are attributed to $\mathrm{OH}^{\square}$

303 bonds and thus show the hydration of the DO sample and possible links with MB molecules 304 through chemisorption. The relatively high peak at $3430 \mathrm{~cm}^{-1}$ confirms the presence of 305 hydroxyl groups and the formation of $\mathrm{Cu}(\mathrm{OH})_{2}$ complexes. A sharp peak observable at 714

$306 \mathrm{~cm}^{-1}$ after $\mathrm{Cu}$ sorption was also noticed by Ippolito et al. and attributed to the presence of $307 \mathrm{CaO}$ [47]. The formation of complexes in the form of $\mathrm{Ca} / \mathrm{Cu}-(\mathrm{OH})_{\mathrm{x}}$ is thus highly probable. A 308 partial ion-exchange mechanism between $\mathrm{Ca}^{2+}$ and $\mathrm{Cu}^{2+}$ in the removal of copper from 309 wastewater was also reported by Walker et al. [25]. The FTIR analysis for the TW sample 310 shown in Figure 8, demonstrated major peaks indicating many functional groups such as $311-\mathrm{NH}_{2}$ and $-\mathrm{OH}$ groups of proteins and glucose; $-\mathrm{CH}$ stretching and $>\mathrm{C}=\mathrm{O}$ ester stretching 312 vibration of triglycerides; this stretching mode conjugated with the $\mathrm{NH}_{2}$ (amide 1 band) [27]. 313 After MB adsorption onto TW two main peaks can be seen at 1383 and $1337 \mathrm{~cm}-{ }^{1}$ and most 314 of the peaks already present are enhanced. The FTIR peaks characteristic of MB molecules 315 overlap with peaks from the TW sample as most chemical groups present in MB are present 
316 in TW. The broad peak visible around $3230-3270 \mathrm{~cm}^{-1}$ is linked to the $\mathrm{N}-\mathrm{H}$ bonding from

317 MB. The peaks around 1737 and $1160 \mathrm{~cm}^{-1}$ account for the sulphate groups and are naturally

318 present on the TW sample [48]. It is thus interesting to note that after $\mathrm{Cu}$ adsorption this peak

319 is relatively high, thus indicating a sorption of the sulphate groups from the copper salt as

320 well. Negatively charged ions are necessary to counter-balance the sorption of $\mathrm{Cu}^{2+}$ onto TW,

321 also $\mathrm{SO}_{4}{ }^{2 \square}$ is involved in this process. The sorption of both anions and cations is

322 characteristics of physisorption where both ions co-habit in the diffuse layer [49]. EDX

323 analysis coupled with FTIR investigation showed that surface complexation was the main

324 route of removal for $\mathrm{Cu}$ and $\mathrm{MB}$ by $\mathrm{DO}$. Using data from the $\mathrm{pH}$ study it can be concluded

325 that physisorption was responsible for most of $\mathrm{Cu}$ and $\mathrm{MB}$ adsorption onto $\mathrm{TW}$ even if

326 chemisorption was also contributing to the removal of MB by TW.

\section{3.6. Comparison of adsorption capacity with composite adsorbents}

328 A comparison was carried out between the results of the adsorption capacities of tea waste

329 and dolomite multi-adsorbent system dyes and chemically prepared composite adsorbents

330 towards copper ions and methylene blue (Table 4). Ignoring the different experimental

331 conditions used, it can be seen that the adsorption capacities obtained in this study are

332 comparable with those reported by other researchers. This indicates that tea waste and

333 dolomite multi-adsorbents can be classified as one of the effective adsorption systems for this

334 purpose. The two substances in this investigation were physically mixed without any

335 chemical modifications. Once more, this implies that environmentally friendly composite

336 adsorbents can be produced at low cost and very little effort without any chemical alterations. 
342 The selectivity of tea waste and dolomite for copper and methylene blue and the influence of 343 contact time, solution $\mathrm{pH}$ and initial pollutant concentration on adsorption capacities was 344 examined. The adsorption kinetics could be explained by the pseudo-second-order model. 345 The maximum removal capacity of $\mathrm{Cu}$ onto both adsorbents was achieved at $\mathrm{pH}=4.5$, while 346 MB was optimally removed over the $\mathrm{pH}$ range studied with removal percentages of over $34790 \%$. The present investigation indicated that tea waste and dolomite can concurrently be 348 effectively used to remove copper and methylene blue from aqueous solution. Further studies 349 are required to examine the effect of the chemistry of solution and the design and scale-up of 350 fixed-bed adsorption columns. 
367 [1] A.B. Albadarin, C. Mangwandi, G.M. Walker, S.J. Allen, M.N. Ahmad, Biosorption

368 characteristics of sawdust for the removal of Cd(II) Ions: Mechanism and thermodynamic 369 studies, Chemical Engineering Transactions, (2011) 1297-1302.

370 [2] G. Zhao, H. Zhang, Q. Fan, X. Ren, J. Li, Y. Chen, X. Wang, Sorption of copper(II) onto 371 super-adsorbent of bentonite-polyacrylamide composites, Journal of Hazardous Materials, 372173 (2010) 661-668.

373 [3] P.A. Brown, J.M. Brown, S.J. Allen, The application of kudzu as a medium for the 374 adsorption of heavy metals from dilute aqueous wastestreams, Bioresource Technology, 78 375 (2001) 195-201.

376 [4] Maria Visa, Cristina Bogatu, A. Duta, Simultaneous adsorption of dyes and heavy metals 377 from multicomponent solutions using fly ash, Applied Surface Science, 256 (2010) 54863785491.

379 [5] B. Noroozi, G.A. Sorial, Applicable models for multi-component adsorption of dyes: A 380 review, Journal of Environmental Sciences, 25 (2013) 419-429.

381 [6] George Z. Kyzas, Nikolaos K. Lazaridis, M. Kostoglou, On the simultaneous adsorption 382 of a reactive dye and hexavalent chromium from aqueous solutions onto grafted chitosan, 383 Journal of Colloid and Interface Science, 407 (2013) 432-441.

384 [7] Y.S. Al-Degs, A.H. El-Sheikh, M.A. Al-Ghouti, B. Hemmateenejad, G.M. Walker, Solid385 phase extraction and simultaneous determination of trace amounts of sulphonated and azo 386 sulphonated dyes using microemulsion-modified-zeolite and multivariate calibration, Talanta, $387 \quad 75$ (2008) 904-915.

388 [8] S.J. Allen, G. McKay, J.F. Porter, Adsorption isotherm models for basic dye adsorption 389 by peat in single and binary component systems, Journal of Colloid and Interface Science, 390280 (2004) 322-333.

391 [9] G.M. Walker, L. Hansen, J.-A. Hanna, S.J. Allen, Kinetics of a reactive dye adsorption 392 onto dolomitic sorbents, Water Research, 37 (2003) 2081-2089.

393 [10] Pranay A Raut, Monal Dutta, Sonali Sengupta, J.K. Basu, Alumina-carbon composite as 394 an effective adsorbent for removal of Methylene Blue and Alizarin Red-s from aqueous 395 solution, Indian Journal of Chemical Technology, 20 (2013) 15-20.

396 [11] Yuttasak Chammui, Ponlayuth Sooksamiti, Wimol Naksata, Sakdiphon Thiansem, O.-a. 397 Arqueropanyo, Removal of arsenic from aqueous solution by adsorption on Leonardite, 398 Chemical Engineering Journal, 240 (2014) 202-210.

399 [12] Yahya S. Al-Degs, Amjad H. El-Sheikh, Mohammad A. Al-Ghouti, Bahram 400 Hemmateenejad, G.M. Walker, Solid-phase extraction and simultaneous determination of 401 trace amounts of sulphonated and azo sulphonated dyes using microemulsion-modified402 zeolite and multivariate calibration, Talanta, 75 (2008) 904-915.

403 [13] L. Wang, A. Wang, Adsorption characteristics of Congo Red onto the 404 chitosan/montmorillonite nanocomposite, Journal of Hazardous Materials, 147 (2007) 979405985.

406 [14] M.R. Awual, M. Ismael, T. Yaita, S.A. El-Safty, H. Shiwaku, Y. Okamoto, S. Suzuki, 407 Trace copper(II) ions detection and removal from water using novel ligand modified 408 composite adsorbent, Chemical Engineering Journal, 222 (2013) 67-76.

409 [15] A. Ely, M. Baudu, M.O.S.A.O. Kankou, J.-P. Basly, Copper and nitrophenol removal by 410 low cost alginate/Mauritanian clay composite beads, Chemical Engineering Journal, 178 411 (2011) 168-174.

412 [16] M. Visa, L. Isac, A. Duta, Fly ash-activated carbon powder composites for dyes and 413 heavy metals removal, Advanced Materials Research, 79-82 (2009) 243-246. 
414 [17] K.Y. Ho, G. McKay, K.L. Yeung, Selective adsorbents from ordered mesoporous silica, 415 Langmuir, 19 (2003) 3019-3024.

416 [18] A.A. Khouloud, E.W. Dale, Prediction of adsorption from multicomponent solutions by 417 acti-vated carbon using single-solute parameters. Part II - proposed equation, AAPS 418 PharmSciTech, 3 (2002) 1-8.

419 [19] K.K.H. Choy, J.F. Porter, G. McKay, Intraparticle diffusion in single and 420 multicomponent acid dye adsorption from wastewater onto carbon, Chemical Engineering 421 Journal, 103 (2004) 133-145.

422 [20] P.V. Brady, J.L. Krumhansl, H.W. Papenguth, Surface complexation clues to dolomite growth, Geochimica et Cosmochimica Acta, 60 (1996) 727-731.

[21] S.J. Allen, B. Koumanova, Decolourisation of water/wastewaterusing adsorption: review, Journal of the University of Chemical Technology and Metallurgy, 40 (2005) 175192.

[22] N.S. Mokgalaka, R.I. McCrindle, B.M. Botha, Multielement analysis of tea leaves by inductively coupled plasma optical emission spectro metry using slurry nebulization, Journal of Analytical Atomic Spectrometry, 19 (2004) 1375-1378.

[23] B.H. Hameed, Spent tea leaves: A new non-conventional and low-cost adsorbent for removal of basic dye from aqueous solutions, Journal of Hazardous Materials, 161 (2009) 753-759.

[24] C. Mangwandi, A.B. Albadarin, L. JiangTao, S. Allen, G.M. Walker, Development of a value-added soil conditioner from high shear co-granulation of organic waste and limestone powder, Powder Technology, 252 (2014) 33-41.

[25] G.M. Walker, G. Connor, S.J. Allen, Copper (II) Removal onto Dolomitic Sorbents, Chemical Engineering Research and Design, 82 (2004) 961-966.

[26] A.B. Albadarin, C. Mangwandi, A.a.H. Al-Muhtaseb, G.M. Walker, S.J. Allen, M.N.M. Ahmad, Kinetic and thermodynamics of chromium ions adsorption onto low-cost dolomite adsorbent, Chemical Engineering Journal, 179 (2012) 193-202.

[27] A.B. Albadarin, C. Mangwandi, G.M. Walker, S.J. Allen, M.N.M. Ahmad, M. Khraisheh, Influence of solution chemistry on $\mathrm{Cr}(\mathrm{VI})$ reduction and complexation onto datepits/tea-waste biomaterials, Journal of Environmental Management, 114 (2013) 190-201.

[28] K.A.G. Gusmão, L.V.A. Gurgel, T.M.S. Melo, L.F. Gil, Adsorption studies of methylene blue and gentian violet on sugarcane bagasse modified with EDTA dianhydride (EDTAD) in aqueous solutions: Kinetic and equilibrium aspects, Journal of Environmental Management, 118 (2013) 135-143.

[29] C. Moreno-Castilla, Adsorption of organic molecules from aqueous solution on carbon materials, Carbon, 42 (2004) 83-94.

[30] S. Lagergren, Zur theorie der sogenannten adsorption gelöster stoffe KungligaSvenska Vetenskapsakademiens, Handlingar, 24 (1898) 1-39.

[31] Y.S. Ho, G. McKay, Pseudo-second order model for sorption process, Process Biochemistry 34 (1999) 451-465.

[32] Weifeng Liu, Jian Zhang, Cheng Cheng, Guipeng Tian, C. Zhang, Ultrasonic-assisted sodium hypochlorite oxidation of activated carbons for enhanced removal of $\mathrm{Co}$ (II) from aqueous solutions Original Research Article, Chemical Engineering Journal, 175 (2011) 2432.

[33] Meng-Wei Wan, Chan-Ching Wang, C.-M. Chen, The adsorption study of copper removal by chitosan-coated sludge derived from water treatment plant, International Journal of Environmental Science and Development, 4 (2013) 545-550.

[34] P. Wang, M. Cao, C. Wang, Y. Ao, J. Hou, J. Qian, Kinetics and thermodynamics of adsorption of methylene blue by a magnetic graphene-carbon nanotube composite, Applied Surface Science, 290 (2014) 116-124. 
464 [35] M.M. Ayad, A. Abu El-Nasr, J. Stejskal, Kinetics and isotherm studies of methylene

465 blue adsorption onto polyaniline nanotubes base/silica composite, Journal of Industrial and

466 Engineering Chemistry, 18 (2012) 1964-1969.

467 [36] Yoann Glocheux, Martín Méndez Pasarín, Ahmad B. Albadarin, Stephen J. Allen, G.M.

468 Walker, Removal of arsenic from groundwater by adsorption onto an acidified laterite by469 product, Chemical Engineering Journal, 228 (2013) 565-574.

470 [37] M.A. Hossain, H.H. Ngo, W.S. Guo, T. Setiadi, Adsorption and desorption of copper(II) 471 ions onto garden grass, Bioresource Technology, 121 (2012) 386-395.

472 [38] E.N. El Qada, S.J. Allen, G.M. Walker, Adsorption of Methylene Blue onto activated

473 carbon produced from steam activated bituminous coal: A study of equilibrium adsorption

474 isotherm, Chemical Engineering Journal, 124 (2006) 103-110.

475 [39] I. Langmuir, The adsorption of gases on plane surfaces of glass, mica and platinum, 40 476 (1918) 1361-1403.

477 [40] I. Langmuir, The constitution and fundamental properties of solids and liquids, Journal 478 of the American Chemical Society 38 (1916) 2221-2295.

479 [41] H.M.F. Freundlich, Over the adsorption in solution, The Journal of Physical Chemistry 48057 (1906) 385-471.

481 [42] Samar K. Theydan, M.J. Ahmed, Adsorption of methylene blue onto biomass-based 482 activated carbon by $\mathrm{FeCl}_{3}$ activation: Equilibrium, kinetics, and thermodynamic studies, Journal of Analytical and Applied Pyrolysis, 97 (2012) 116-122.

[43] A. Duffy, G.M. Walker, S.J. Allen, Investigations on the adsorption of acidic gases using activated dolomite, Chemical Engineering Journal, 117 (2006) 239-244.

[44] V. Vimonses, B. Jin, C.W.K. Chow, Insight into removal kinetic and mechanisms of anionic dye by calcined clay materials and lime, Journal of Hazardous Materials, 177 (2010) 420-427.

489 [45] M.A. Al-Ghouti, J. Li, Y. Salamh, N. Al-Laqtah, G. Walker, M.N.M. Ahmad, 490 Adsorption mechanisms of removing heavy metals and dyes from aqueous solution using 491 date pits solid adsorbent, Journal of Hazardous Materials, 176 (2010) 510-520.

492 [46] P. Papadopoulos, D.L. Rowell, The reactions of copper and zinc with calcium carbonate 493 surfaces, European Journal of Soil Science, 40 (1989) 39-48.

494 [47] J.A. Ippolito, D.G. Strawn, K.G. Scheckel, J.M. Novak, M. Ahmedna, M.A. Niandou, 495 Macroscopic and molecular investigations of copper sorption by a steam-activated biochar, 496 Journal of Environmental Quality, 41 (2012) 1150-1156.

497 [48] E. Malkoc, Y. Nuhoglu, Fixed bed studies for the sorption of chromium(VI) onto tea 498 factory waste, Chemical Engineering Science, 61 (2006) 4363-4372.

499 [49] A. Thompson, K.W. Goyne, Introduction to the sorption of chemical constituents in 500 soils, Nature Education Knowledge, 4 (2012) 7-11. 
Table 1: Pseudo first-order and pseudo second-order model constants for $\mathrm{Cu}(\mathrm{II})$ and $\mathrm{MB}$ sorption onto tea waste and dolomite at different systems.

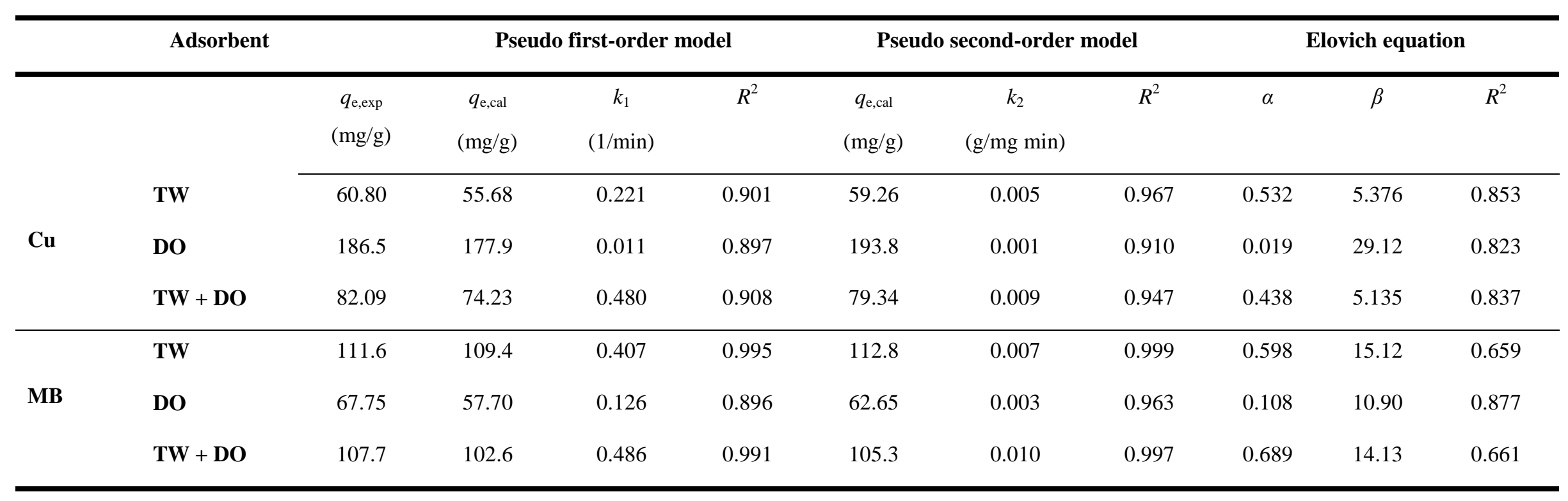


Table 2: The Langmuir and Freundlich isotherm constants for $\mathrm{Cu}(\mathrm{II})$ and MB sorption onto tea waste and dolomite at different systems.

\begin{tabular}{|c|c|c|c|c|c|c|c|c|}
\hline & \multicolumn{2}{|c|}{ Adsorbent } & \multicolumn{3}{|c|}{ Langmuir isotherm model } & \multicolumn{3}{|c|}{ Freundlich isotherm model } \\
\hline & & $q_{\max }$ & $b$ & $R_{\mathrm{L}}\left(\times 10^{3}\right)$ & $R^{2}$ & $K_{\mathrm{F}}$ & $n$ & $R^{2}$ \\
\hline \multirow{2}{*}{$\mathbf{C u}$} & TW & 77.31 & 0.015 & 8.549 & 0.960 & 2.402 & 1.492 & 0.979 \\
\hline & TW + DO & 38.2 & 0.239 & 1.094 & 0.984 & 12.69 & 3.764 & 0.922 \\
\hline \multirow[b]{2}{*}{ MB } & TW & 130.5 & 0.271 & 0.376 & 0.946 & 28.02 & 1.564 & 0.912 \\
\hline & DO & 113.3 & 0.018 & 6.493 & 0.901 & 4.256 & 1.520 & 0.925 \\
\hline
\end{tabular}


Table 3: EDX analysis results expressed in \% w/w.

\begin{tabular}{lcccccc}
\hline & \multicolumn{7}{c}{ Elemental composition in \% w/w } \\
\hline & $\mathbf{C}$ & $\mathbf{O}$ & $\mathbf{M g}$ & $\mathbf{S}$ & $\mathbf{C a}$ & $\mathbf{C u}$ \\
\cline { 2 - 7 } DO-Cu & 22.80 & 29.88 & 2.77 & 4.33 & 14.55 & 25.66 \\
DO-MB & 18.42 & 43.33 & 6.64 & 6.21 & 25.40 & - \\
TW-Cu & 65.41 & 29.82 & - & 0.46 & - & 4.31 \\
TW-MB & 71.60 & 27.00 & - & 1.40 & - & - \\
\hline
\end{tabular}


Table 4: Comparison of adsorption capacities of the TW:DO system with composite adsorbents in literature.

\begin{tabular}{llllll}
\hline Adsorbents & Pollutant & Adsorption & Max conc. & Best fit isotherm & Ref. \\
& $(\mathrm{Cu}$ or MB) & capacity (mg/g) & Studied & & \\
\hline Bentonite-polyacrylamide & $\mathrm{Cu}(\mathrm{II})$ & 32.8 & $15 \mathrm{ppm}$ & Langmuir & {$[2]$} \\
Ligand modified composite & $\mathrm{Cu}(\mathrm{II})$ & 182.1 & $60 \mathrm{ppm}$ & Langmuir & {$[14]$} \\
Alginate/Mauritanian clay (Na-ZS26) & $\mathrm{Cu}(\mathrm{II})$ & 15.1 & $200 \mathrm{ppm}$ & Langmuir & {$[15]$} \\
Tea waste + Dolomite & $\mathrm{Cu}(\mathrm{II})$ & 38.1 & $100 \mathrm{ppm}$ & Langmuir & Current study \\
Alumina-carbon & $\mathrm{MB}$ & 1152.3 & $420 \mathrm{ppm}$ & Redlich-Peterson & {$[10]$} \\
Magnetic graphene-carbon nanotube & $\mathrm{MB}$ & 65.79 & $35 \mathrm{ppm}$ & Langmuir & {$[34]$} \\
Polyaniline nanotubes base/silica & $\mathrm{MB}$ & 10.3 & $10 \mathrm{ppm}$ & Langmuir & {$[35]$} \\
Tea waste + Dolomite & $\mathrm{MB}$ & 150.4 & $75 \mathrm{ppm}$ & Langmuir & Current study \\
\hline
\end{tabular}




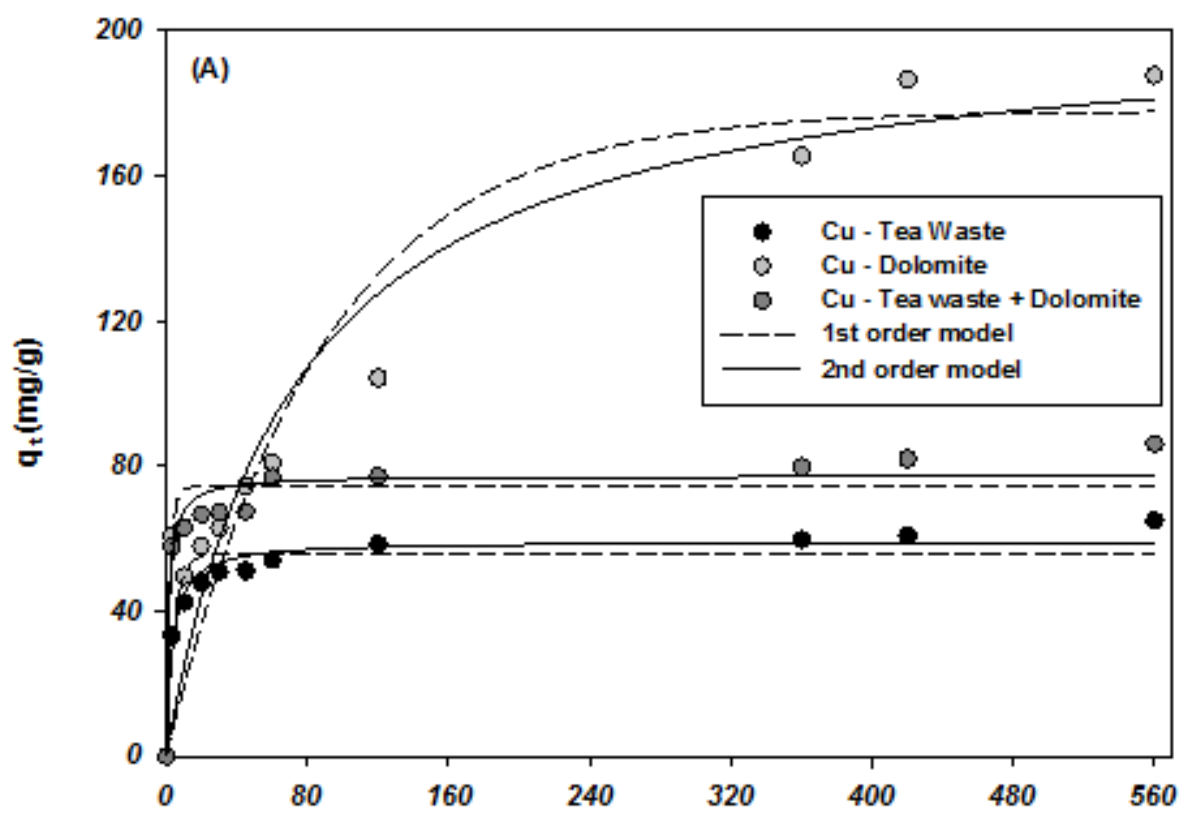

Contact time (min)

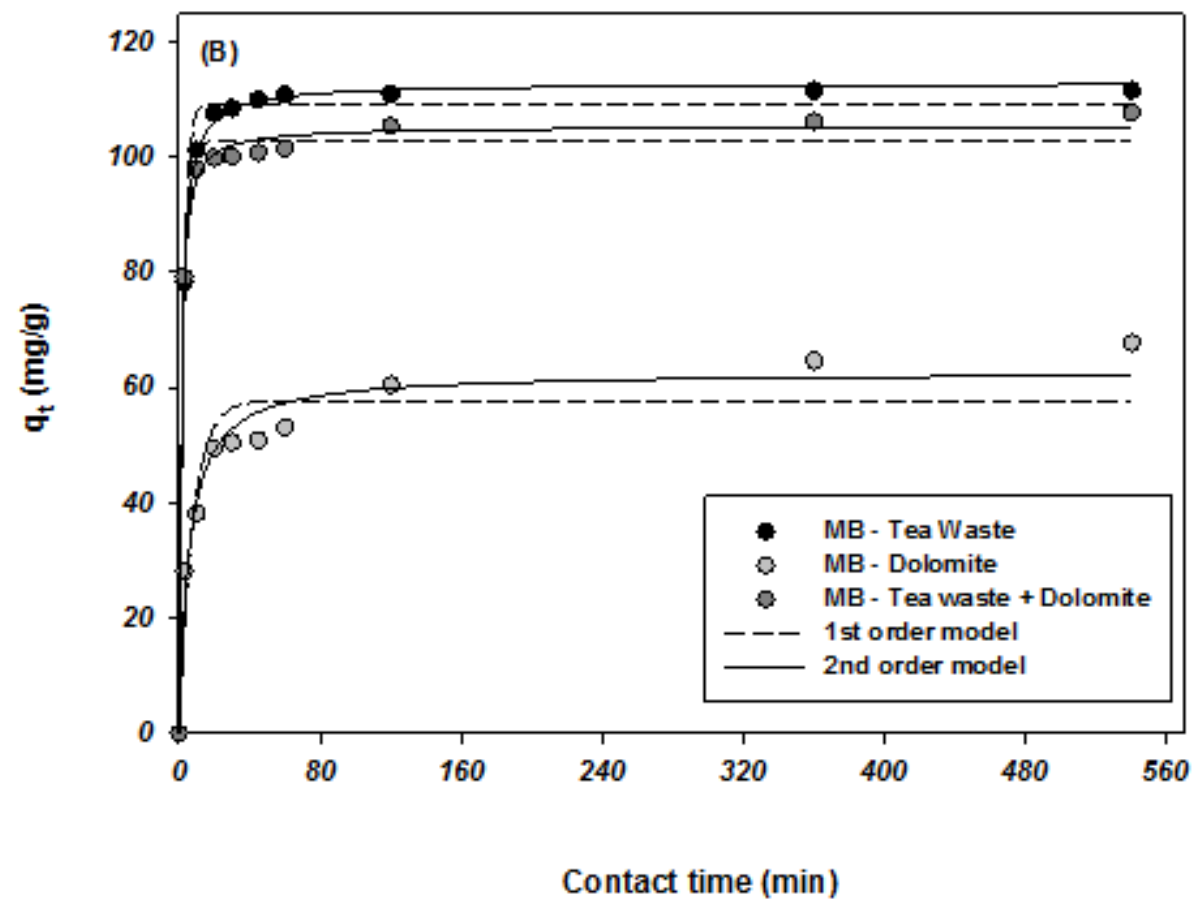

Figure 1: The fitting of pseudo first- and second-order models for $\mathrm{Cr}$ (II) and MB removal onto TW and DO. 

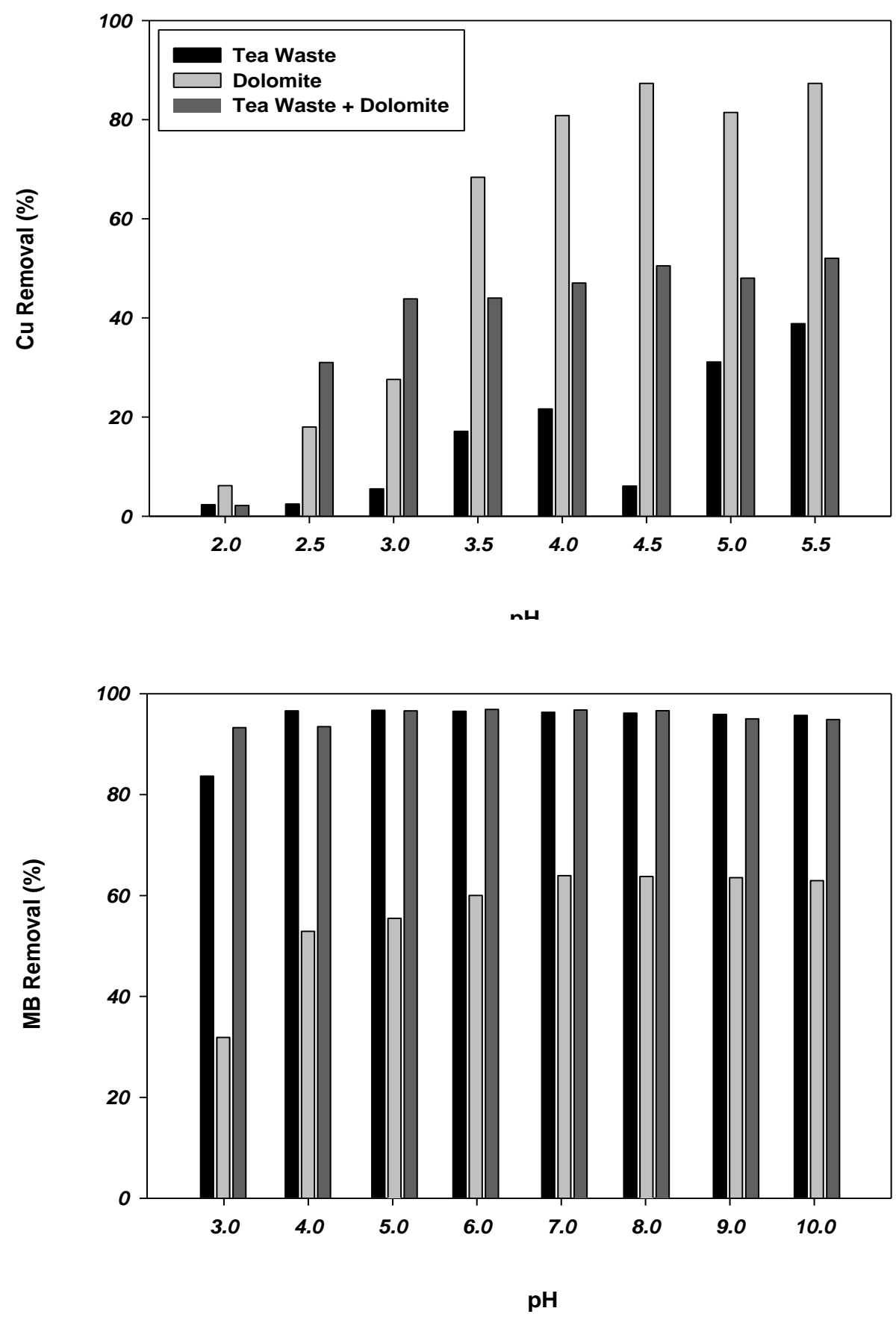

Figure 2: Effect of $\mathrm{pH}$ on the removal of $\mathrm{Cu}(\mathrm{II})$ and $\mathrm{MB}$ onto TW and $\mathrm{DO}$. 

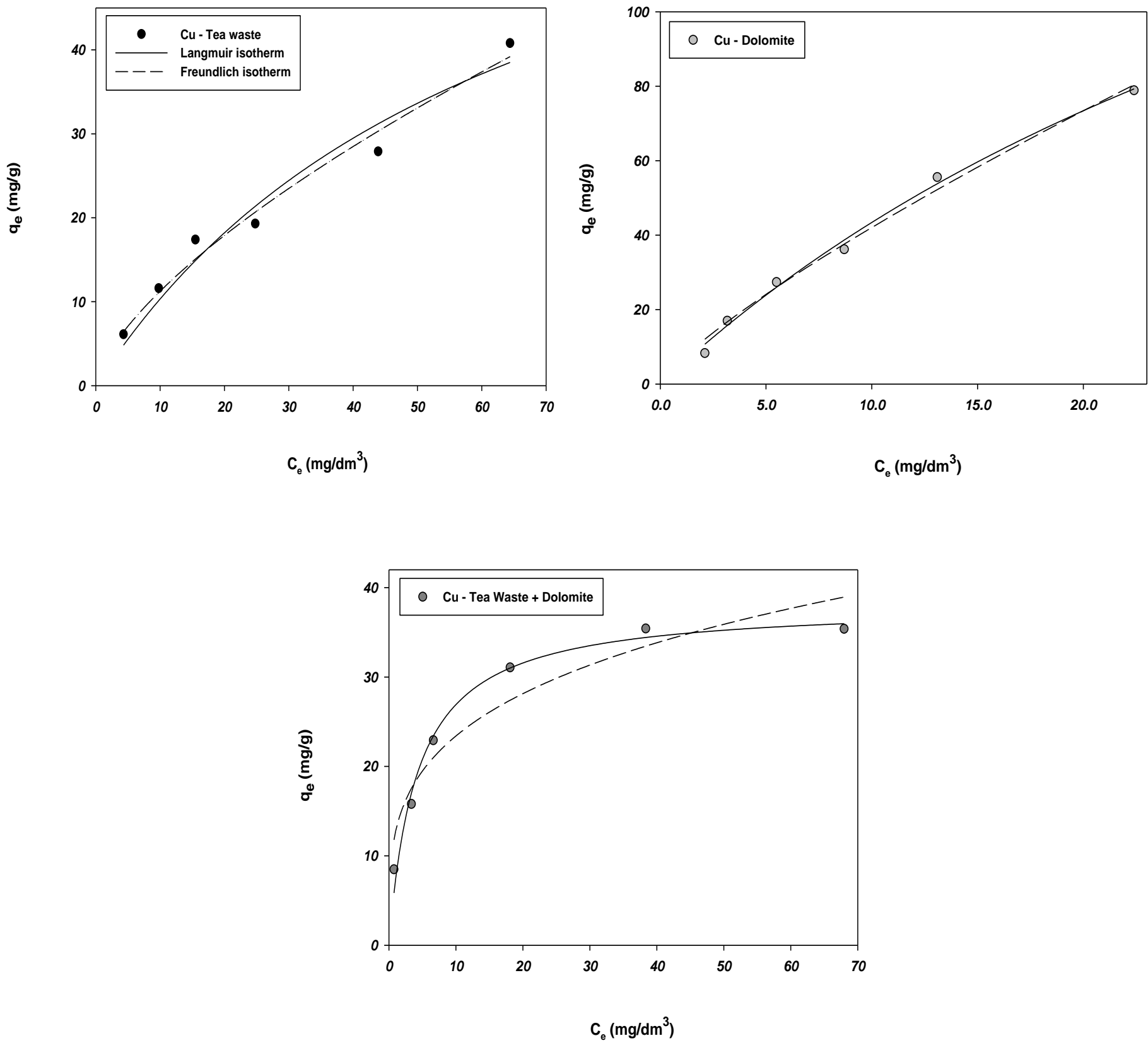

Figure 3: Non-linear forms of Langmuir and Freundlich adsorption isotherm plots of $\mathrm{Cu}$ adsorption onto Tea Waste (TW) and Dolomite (DO). 

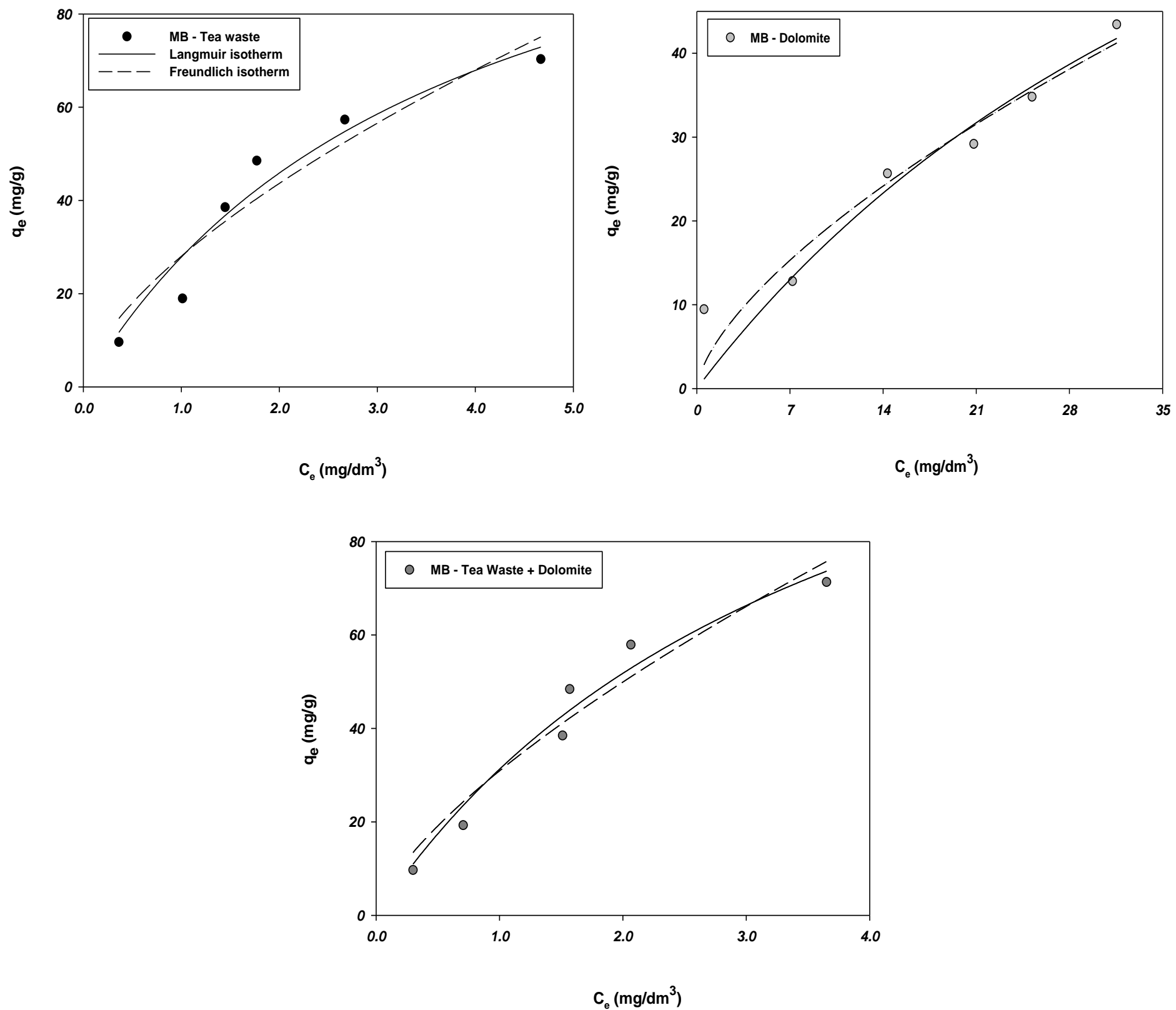

Figure 4: Non-linear forms of Langmuir and Freundlich adsorption isotherm plots of MB onto Tea Waste (TW) and Dolomite (DO). 

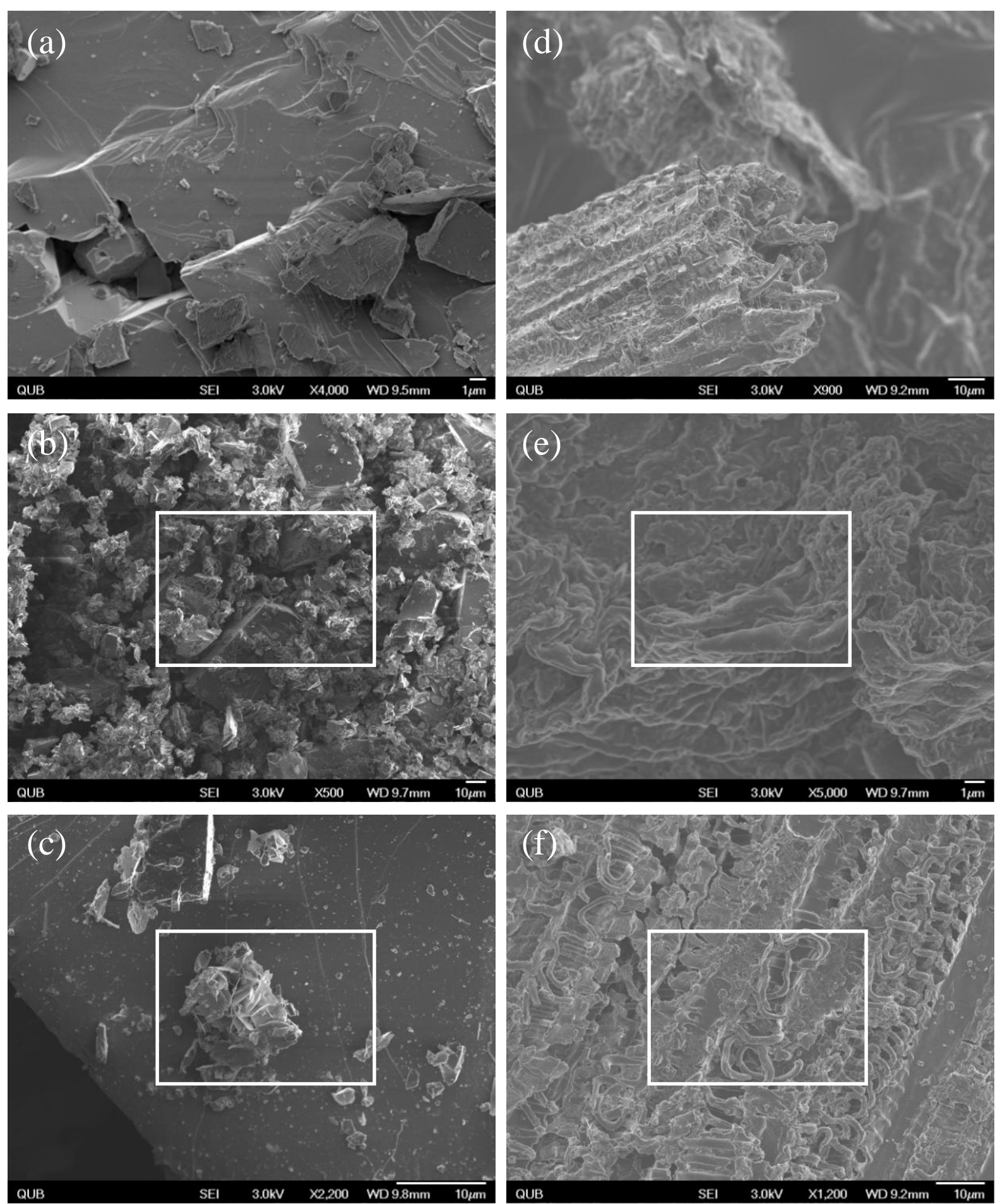

Figure 5: SEM images of Dolomite and Tea Waste before adsorption experiments (a) and (d), after Cu adsorption (b) and (e) and after MB adsorption (c) and (f) respectively. 

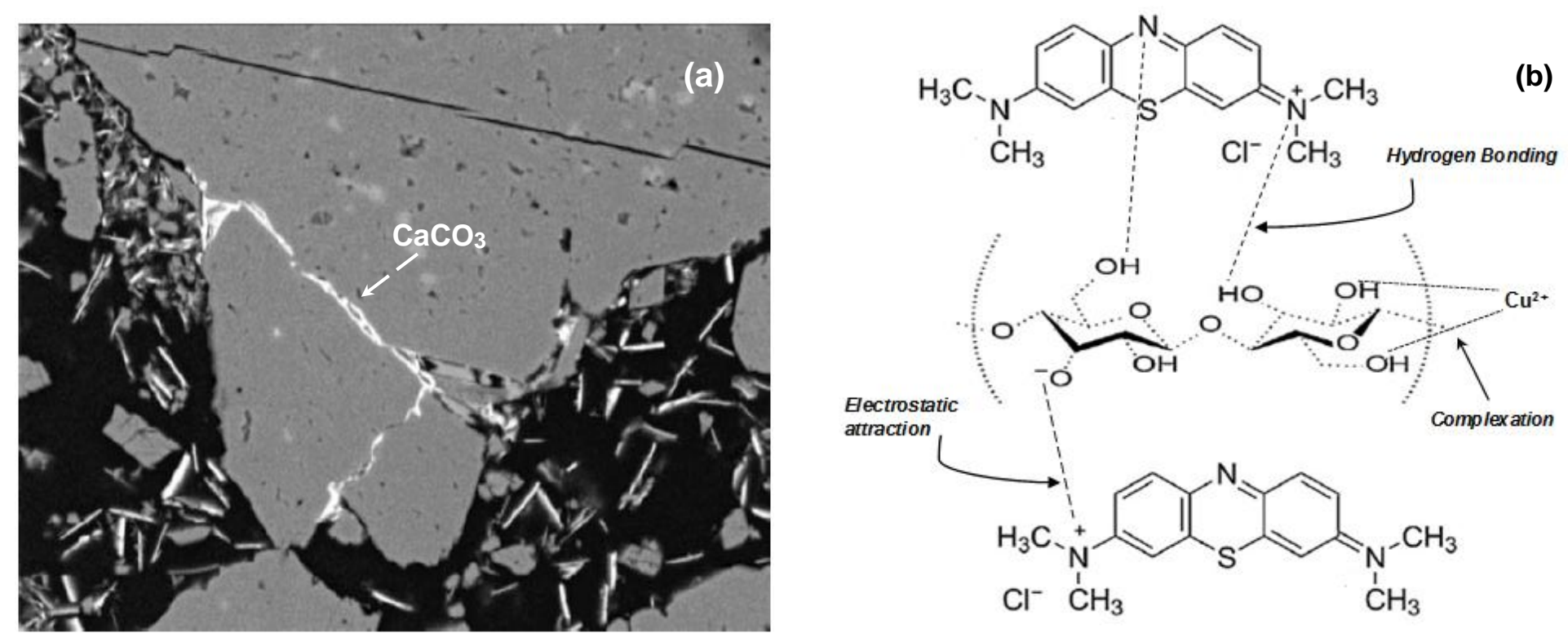

Figure 6: (a) Copper surface precipitation within cracks on dolomite (After Ref [25]) and (b) Metal ions and dye molecule removal through electrostatic attraction and hydrogen bonding (After Ref [45]). 

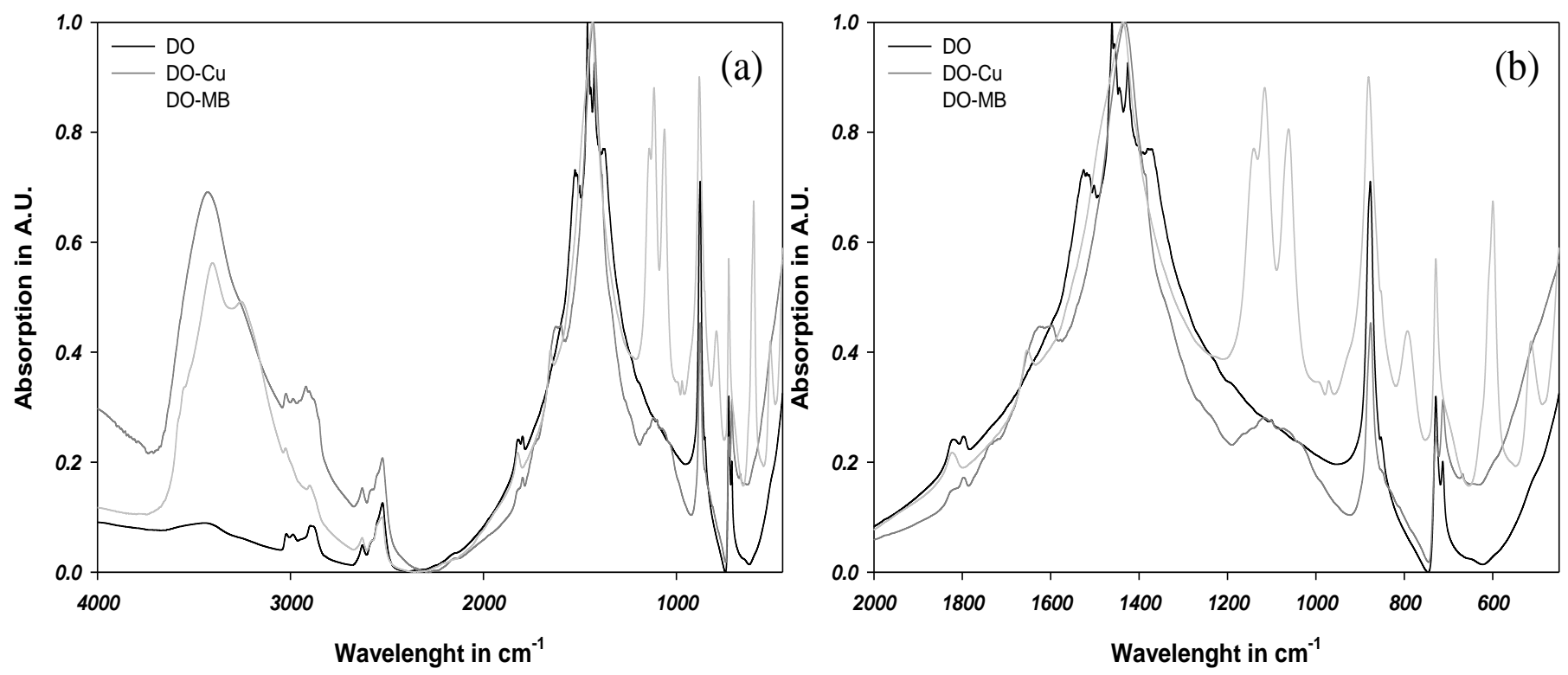

Figure 7: FTIR spectra of DO before and after adsorption with $\mathrm{Cu}$ and $\mathrm{MB}$, (a) full spectrum and (b) close up onto the 2000 to $450 \mathrm{~cm}^{-1}$ region. The spectra are normalised and un-shifted.
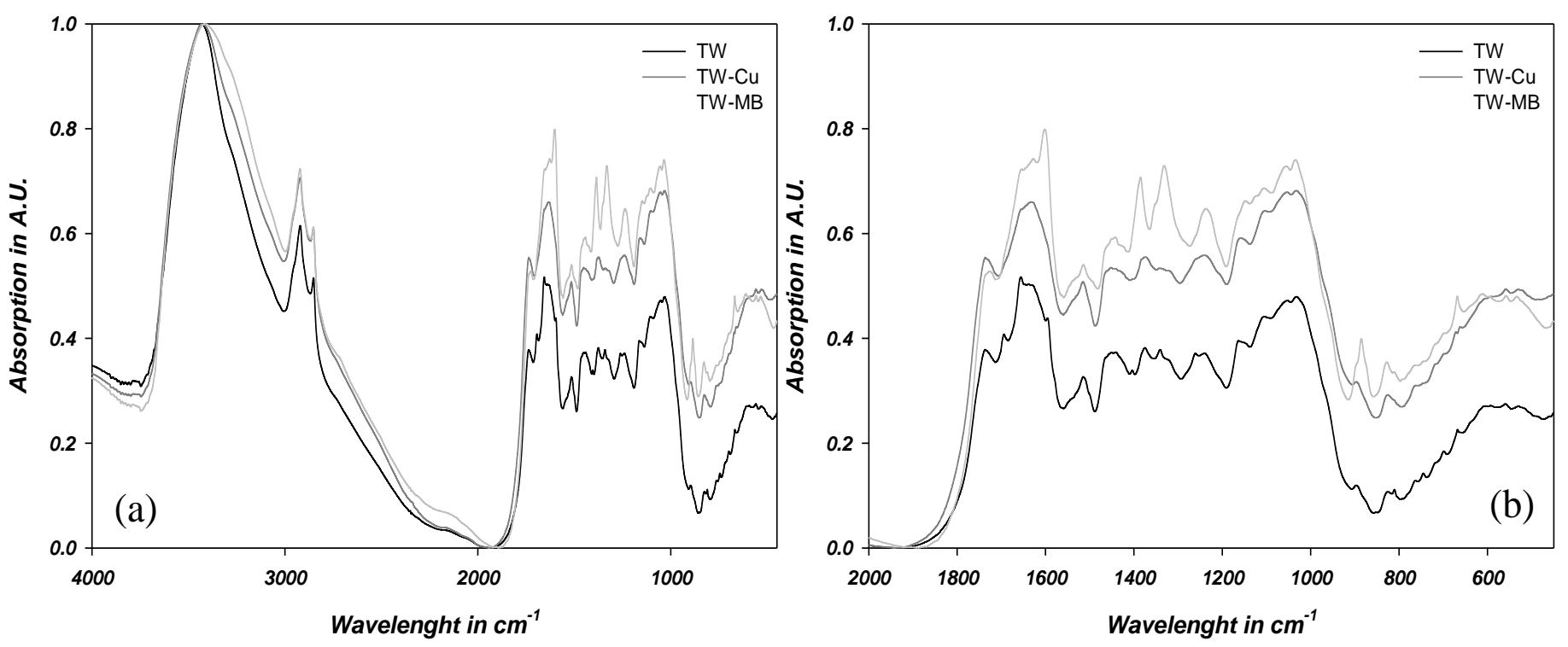

Figure 8: FTIR spectra of TW before and after adsorption with $\mathrm{Cu}$ and $\mathrm{MB}$, (a) full spectrum and (b) close up onto the 2000 to $450 \mathrm{~cm}^{-1}$ region. The spectra are normalised and un-shifted. 
Supplementary Material

Click here to download Supplementary Material: SUPPLEMENTRY MATERIAL FIGURE S1.docx

Clck here to download Supplementary Material: SUPPLEMENTRY MATERIAL FIGURE S1.dOCX

.

(1) 更 (1) (1) (1) (1) . . . . . . . . 